\title{
The Determinants and Outcomes of Absence Behavior: A Systematic Literature Review
}

\author{
Vedrana Čikeš *(i), Helga Maškarin Ribarić ${ }^{(1)}$ and Kristina Črnjar ${ }^{(1)}$ \\ Faculty of Tourism and Hospitality Management, University of Rijeka, Primorska 42, P.O. Box 97, 51410 Opatija, \\ Croatia; helgam@fthm.hr (H.M.R.); kcrnjar@fthm.hr (K.Č.) \\ * Correspondence: vedrana.cikes@fthm.hr; Tel.: +385-51-689-311
}

Received: 1 June 2018; Accepted: 19 July 2018; Published: 24 July 2018

\begin{abstract}
This research aims to identify and analyze the frequency of the researched determinants and outcomes of absenteeism and thus create an extensive pool of knowledge that can be used for further research. A systematic review, based on Tranfield, Denyer, and Smart's guidelines of 2003, was used. An electronic search of the Scopus database led to the inclusion of 388 peer-reviewed research articles. Finally, 100 top-quality articles were analyzed using content analysis. This article provides several starting points for practitioners and researchers when investigating absenteeism and its potential determinants and outcomes. It also shows that there is an evident imbalance between empirical research dealing with determinants and research dealing with absenteeism outcomes. Employee attitudes stand out among the most repetitive absenteeism causes, while turnover, organizational health, and loss of productivity are some of the most researched absenteeism outcomes. Most research takes place in the manufacturing industries, followed by hospitals and other public service organizations, banks, and insurance companies. This systematic literature review is the first known attempt of this kind of review of the causes and consequences of absence behavior. It covers a wide range of literature published from 1969 until today and includes more than 150 different absenteeism determinants and outcomes.
\end{abstract}

Keywords: absenteeism; determinants; outcomes; systematic literature review

\section{Introduction}

The human element plays a significant role in any organization. Employees and human resource management are key determinants of service quality, customer satisfaction and loyalty, competitive advantage, organizational performance, and business success (Bitner et al. 1990; Nickson et al. 2002; Schneider et al. 2003). Many theories, models, and empirical studies in the management literature that underline the crucial role of human resources for organizations support this belief.

One of the most important issues that human resource managers are dealing with is managing their staff's absence behavior, i.e., absenteeism. Absenteeism is a temporary absence from work (temporary withdrawal from an organization) for reasons such as illness, death in the family, or other personal issues (Mathis and Jackson 2004). It is also interpreted as an employee's intentional or habitual absence from work (Cucchiella et al. 2014). According to the literature, there are several types of absenteeism. The most common type is sick leave (Duff et al. 2015; Løkke et al. 2006; Pizam and Thornburg 2000), while some authors consider vacation, maternity leave, military duty, education absence, etc. as forms of absenteeism, too. Some authors differentiate involuntary absenteeism (e.g., certified sickness, funeral attendance) and voluntary absenteeism (e.g., vacation, uncertified sickness) (March and Simon 1958). (Gibson 1966; Johns 1978) distinguish between authorized and unauthorized absenteeism, while (Blau 1985) and (Cheloha and Farr 1980) divide absenteeism into organizationally excused and organizationally unexcused categories, with types such as sickness, jury duty, religious 
holidays, funeral leave, and transportation problems belonging to the category of excused forms of absence. Absenteeism is relatively easy to measure. There are two kinds of absence metrics: time lost and absence frequency. Time-lost measures express absenteeism as a sum of units of time (e.g., hours or days) away from work (Steel 2003), while absence frequency is the number of absences in a specific period of time regardless of duration (Chadwick-Jones et al. 1971).

Excessive absenteeism can have a serious impact on any company. The seriousness of this impact is the subject of extensive debate. Some of the negative consequences of absenteeism are high costs, such as direct compensation costs or replacement costs, as well as loss of productivity (Mathis and Jackson 2004). The importance of studying absenteeism lies in the fact that a better understanding of absence behavior can lead to its successful management.

To address this issue, the aim of this study is to identify, summarize, and analyze the antecedents and consequences of absenteeism, as well as their relation to absenteeism itself, in the largest database of peer-reviewed literature-Scopus_-using a systematic review methodology. This is the first known attempt of a systematic review of the aforementioned subject. A total of 388 articles were reviewed. Accordingly, three research questions were formulated.

RQ1. What are the most researched determinants and outcomes of accruing employee absence behavior?

RQ 2. How do the related determinants influence absence behavior?

RQ 3. What kind of impact can absenteeism have on related outcomes?

The aim of the first research question is to identify the determinants and outcomes of incurring absenteeism as reported in the literature and highlight the most repetitive. The second research question aims to identify a positive or a negative impact of related determinants on absenteeism, while the third research question intends to identify a positive or a negative impact of absenteeism on related outcomes.

The next section gives an overview of the existing literature reviews on absenteeism determinants and/or outcomes. Section 3 explains the systematic review methodology used in this study, with all the inclusion and exclusion criteria. Section 4 summarizes the main results of the study. This is followed by a discussion section, including recommendations for further research. Finally, the conclusions of the study and limitations of this research are presented in Section 6.

\section{Theoretical Background}

Absence behavior has been intensively researched for more than five decades. The first significant papers on the systematization of absenteeism causes and consequences date back to the 1970s. The approaches to the classification of factors that influence absence behavior, as well as the consequences of absenteeism, differ from one author to another. This chapter offers a short overview of the most significant authors and their review papers which deal with the determinants and outcomes of absenteeism.

In the 1970s, (Muchinsky 1977) conducted a narrative review of the relationship between absenteeism and personal, attitudinal, and organizational variables. Other than these absenteeism determinants, he researched the relationship between absenteeism and turnover, which represent two of the most important withdrawal behaviors in any organization. Muchinsky also examined absenteeism from several perspectives, including the psychometric problems of measurement, as well as efforts to deal with this phenomenon at a very practical level, including possible solutions for the reduction of employee absenteeism.

(Rhodes and Steers 1981) developed an all-inclusive model of absenteeism that consisted of 8 factor groups which have a possible effect on employee absenteeism: Job situation, Personal characteristics, Pressures to attend, Job satisfaction, Employee Values and Job Expectations, Attendance Motivation, Ability to Attend, and finally, Employee Attendance.

While Muchinsky and Rhodes and Steers mostly dealt with absenteeism determinants, (Goodman and Atkin 1984) went a step further and tried to identify what effect absenteeism has on different 
population levels: the individual worker, adjacent workers, the work group, the organization, other social organizations, and society. Among the negative consequences, they pointed out a loss of rewards, disciplinary action, accidents, greater work stress, lower productivity, and higher costs as most important.

In 1985, (Durand 1985) selected several antecedents and consequences of absenteeism and reviewed absenteeism from two perspectives: industrial-organizational psychology and organizational behavior management. His research was focused on influences that are potentially amenable to change. He found that work unit size, worker responsibility, and organizational scheduling are three potential antecedent influences that could be used to improve employee attendance, and that feedback, rewards, and punishments were shown to be effective attendance control procedures.

In the late 1990s, (Harrison and Martocchio 1998) introduced a new time variable in their research of absenteeism causes and its consequences. They used a time-based system to organize and analyze the causes and consequences of absenteeism in the form of a literature review. In that context, they defined personality and demographic characteristics (gender, age, depression, smoking, heavy drinking, drug abuse, and exercise) as long-term causes of absenteeism. Job-related attitudes and social context represented the mid-term group. Variables belonging to this group, such as high levels of job satisfaction, job involvement, organizational commitment, doing meaningful tasks, working in a group or a culture with strict attendance norms, working in a non-union environment (with less paid sick leave), working on the day shift, and working in an organization with flexible scheduling, all contributed to lower absenteeism. Finally, decision-making mechanisms, such as an employee's intentions regarding attendance, belong to a group of short-term causes.

Furthermore, Harrison and Martocchio indicated some variables that affect absenteeism in a positive way. A person who works under attendance incentives, who can somehow avoid acute stressors such as infections, injuries, and injustices, who can discount the utility of non-work behaviors, who enjoys attending work, and who feels social pressure to attend work with no impediments to do so will have lower absenteeism rates.

In the last 10 years, a systematic literature review methodology was applied on two absenteeism-associated studies (Daouk-Öyry et al. 2014; Davey et al. 2009). Both studies were conducted in a hospital setting.

Daouk-Öyry et al. used the PubMed and CINAHL Plus databases, using articles published between 2007 and 2013 in order to examine the antecedent and outcome variables that concern both turnover and absence behavior. In their research, they proposed a multilevel conceptual model called JOINT (Job, Organization, Individual, National and inTerpersonal factors) for the future investigation of absenteeism and turnover among nurses.

The second group of authors (Davey et al. 2009) used a more comprehensive scope of databases (10 of them, including SCOPUS) and a longer period of time (1986-2006). The objective of their research was to identify individual and organizational predictors of the short-term absences of staff nurses reported in the research literature. They reported that the lack of theory about nursing absenteeism was the reason for the inconsistent results found in their review.

Despite of this rather intensive research on the topic in the form of reviews, the characteristics of past research both leave and open up space for new approaches. The existing review papers dealing with absenteeism causes and consequences are mostly of the narrative type. On the other hand, the methodology approach used in this paper-a systematic review-is relatively new and has not been used so far within the area of economics and management, which is a strongly under-research area in this sense. Moreover, a research review for a period of almost 50 years represents one of the additional values of this paper.

\section{Methodology}

Systematic reviews help to develop a reliable knowledge base for future research in different fields of science. At first, the systematic review was used only in the medical sciences. In 2003, Tranfield, 
Denyer, and Smart adjusted the methodology of the systematic review to the management field. Unlike the traditional literature review, a systematic review improves the quality of the review process and outcomes by employing a transparent and reproducible procedure (Tranfield et al. 2003). In order to produce a quality review, scientists should respect the distinct and exacting principles of transparency, inclusivity, explanation, and heurism (Denyer and Tranfield 2009). According to (Tranfield et al. 2003), a systematic review consists of three steps: (1) a detailed a priori planning of the review, including a precise definition of the aim and research question to be approached in the course of the review; (2) a rigorous execution of the review itself comprising the identification of relevant literature using explicit, reproducible criteria for inclusion and exclusion, which is supported by an appraisal of the quality of the reviewed studies and the strength of their findings; and (3) the reporting and dissemination of the review results. The introductory section explains the aim, the objectives of this review, as well as the research questions (step 1). The selection of the relevant literature (step 2) is presented in the methodological section, while the third step-a synthesis and analytic review of the selected articles and a comprehensive presentation of the results-is presented in the results section.

For the purpose of this study, the Scopus database was chosen as the most relevant source because it is the largest database of peer-reviewed literature. First, a complex keyword search of titles, abstracts and keywords was performed in order to identify studies that focus on the determinants and outcomes of absence behavior. The initial search of the database was undertaken using basic keywords and basic Boolean operators for synonyms: "antecedents" (OR causes, OR determinants, OR predictors), "consequences" (OR outcomes), and "absenteeism" (OR absence behavior). Second, the search was confined to

- document type: article;

- language: English;

- $\quad$ subject area: "Business, Management and Accounting" and "Economics, Econometrics and Finance."

When these criteria were applied, the initial sample resulted in 388 papers in the period from 1969 to 2018 (26 March).

After the analysis of abstracts and full texts, this sample was narrowed to 124 of the most relevant articles. Articles that refer to school absenteeism, theoretical articles, reviews, and meta-analysis were excluded from further analysis.

The last step was the selection of the best-quality articles. Since paper citations serve as a de facto vote on a given article's contribution towards knowledge accumulation and development (Saha et al. 2003), the first 100 articles were selected for the next step.

\section{Results}

This section presents the results of the analysis of the chosen articles. A synthesis of the data started with an analysis of the key design characteristics of each study and the operationalization of the variables involved.

The majority of the selected articles was published over the past 18 years. The distribution of articles by decade was as follows: 1960-1969: 1 article; 1970-1979: 4 articles; 1980-1989: 10 articles; 1990-1999: 27 articles; 2000-2009: 30 articles; 2010-2018: 28 articles.

All 100 articles contain empirical research supported by primary or secondary data. When it comes to study design, both experimental and observational study designs are included. Most of the selected studies used a cross-sectional design (70), 22 of them relied on longitudinal design, 5 were designed as quasi-experimental, and 3 used a mixed-method design.

Data for these studies were collected using different methods. The majority of these studies, 43 of them, used survey questionnaires and organizational databases in combination as their method for data collection. Only databases were relied on in 32 studies, while solely survey questionnaires were used in 20 studies. Other combinations of data collection were also used: database, interview and focus group (1), interview and focus group (1), and interview and survey questionnaire (3). 
The majority of the studies was conducted on an individual level and the population consisted of employees. Most research took place among hospital staff, along with manufacturing, government, and bank employees.

The main geographical source of these empirical studies is the United States of America (38 studies), followed by Canada (9) and Australia (8). Three studies among the selected 100 were conducted among a group of countries.

Most of the 100 articles tested multiple variables of either the causes or consequences of absenteeism. 85 articles only tested antecedents, 8 only tested consequences, and 7 tested both. For a comprehensive view, in Section 4.1 absenteeism determinants and the impact of related determinant on absence behavior are described. The positive and negative outcomes of absenteeism are described in Section 4.2. Afterwards, Table 1 presents the summarized results. The table comprises data about the authors sorted into alphabetic order, the year in which each article was published, the article title, study design, study population, citations, types of absenteeism determinant and outcome, and the relation of the article with absenteeism (positive or negative). A negative mark $(-)$ after a related determinant means that the presence of that determinant decreases absenteeism rates. A positive mark $(+)$ means that absenteeism rates are higher if that determinant is present or its value is growing. When it comes to outcomes, a negative mark means that the higher absenteeism, the lower the outcome rates. A positive mark by the outcome stands for an increase in an outcome correlated with the value of absenteeism.

\subsection{Determinants of Absenteeism}

For the purpose of this article, absence behavior determinants are divided into several categories according to their type: personal, demographic, attitudinal, health-related, organizational, and job determinants.

Among personal factors, conscientiousness, agreeableness and neuroticism are some commonly explored causes of absenteeism (Kolz 1999; Hattrup et al. 1998; Störmer and Fahr 2013). While conscientious and agreeable employees seem to be less absent from work, neuroticism has a positive effect on absence behavior.

Several studies explore age, gender, marital status, the presence of children, race, and ethnicity. While (Garcia 1987) found that age has a positive relationship with absenteeism, (Gellatly 1995), (Gerstenfeld 1969), (Løkke Nielsen 2008), and (Redman et al. 2011) have shown that younger workers are more absent than older ones. Since gender is an important explanatory variable in most absenteeism studies, it is included as an independent variable in all analyses. However, (Vistnes 1997) observed gender as a dependent variable and found that there are some notable differences between the absence behavior of men and women. This study shows a positive correlation between the number of children under the age of six and the likelihood of absence among women. In addition, employees with greater family and personal obligations have a higher frequency of absenteeism (Deery et al. 1995). Married employees are more absent than single ones, and employees belonging to racial or ethnic minorities are absent from work more than their non-minority colleagues (Garcia 1987).

Many authors study attitudes as important determinants of absenteeism in organizations. Job involvement and organizational commitment in interaction show a negative correlation with absence behavior (Blau 1986). The literature on absenteeism suggests that employees might choose to withdraw from an aversive work situation as this makes them dissatisfied. Therefore, it is no surprise that job satisfaction is one of the most researched attitudes (Boon et al. 2014; Yang 2010; Ybema et al. 2010; Cohen and Golan 2007; Steel et al. 2007; Kristensen et al. 2006; Vanden Heuvel 1997; Zaccaro et al. 1991; Rosse and Hulin 1985; Garrison and Muchinsky 1977). In addition, (Wegge et al. 2007) showed that in employees with low job satisfaction the impact of job involvement on absence behavior is much more pronounced than in employees with high job satisfaction. 
Table 1. Absenteeism determinants and outcomes.

\begin{tabular}{|c|c|c|c|c|c|c|c|}
\hline Authors & Year & Title & Study Design & Study Population & Citations & $\begin{array}{l}\text { Determinants and Impact Direction } \\
\text { (Negative }(-) \text { or Positive }(+))\end{array}$ & Outcomes \\
\hline (Ahn et al. 2013) & 2013 & $\begin{array}{l}\text { Construction Workers' Perceptions } \\
\text { and Attitudes Toward Social } \\
\text { Norms as Predictors of Their } \\
\text { Absence Behavior }\end{array}$ & Cross-sectional & $\begin{array}{l}\text { Construction site workers in } \\
\text { Michigan, US }\end{array}$ & 12 & $\begin{array}{l}\text { social controls }(-) \\
\text { awareness of company absence rules }(-)\end{array}$ & \\
\hline $\begin{array}{l}\text { (Arai and Thoursie } \\
\text { 2005) }\end{array}$ & 2005 & $\begin{array}{l}\text { Incentives and Selection in Cyclical } \\
\text { Absenteeism }\end{array}$ & Longitudinal & $\begin{array}{l}\text { Private sector establishments in } \\
\text { Sweden }\end{array}$ & 40 & type of contract (temporary) $(-)$ & \\
\hline (Austrom et al. 1988) & 1988 & $\begin{array}{l}\text { The Single Worker: An Empirical } \\
\text { Exploration of Attitudes, Behavior, } \\
\text { and Well-Being }\end{array}$ & Cross-sectional & $\begin{array}{l}\text { Working population, } \\
\text { English-speaking adults in } \\
\text { Toronto, Canada }\end{array}$ & 3 & $\begin{array}{l}\text { contemporary single persons (not married) } \\
(-)\end{array}$ & \\
\hline (Avery et al. 2012) & 2012 & $\begin{array}{l}\text { Is Relational Demography Relative? } \\
\text { How Employment Status } \\
\text { Influences Effects of } \\
\text { Supervisor-Subordinate } \\
\text { Demographic Similarity }\end{array}$ & Cross-sectional & $\begin{array}{l}\text { Civilians, wage-earning } \\
\text { employees in US }\end{array}$ & 11 & $\begin{array}{l}\text { racioethnic similarity with the supervisor } \\
\text { (mediating effect of employment status } \\
\text { (part-time job)) (-) } \\
\text { gender similarity with the supervisor } \\
\text { (mediating effect of employment status } \\
\text { (part-time job)) (-) }\end{array}$ & \\
\hline $\begin{array}{l}\text { (Bamberger and Biron } \\
\text { 2007) }\end{array}$ & 2007 & $\begin{array}{l}\text { Group Norms and Excessive } \\
\text { Absenteeism: The Role of Peer } \\
\text { Referent Others }\end{array}$ & Cross-sectional & $\begin{array}{l}\text { Production workers employed } \\
\text { (for at least a year) at a food } \\
\text { manufacturing enterprise in } \\
\text { Israel }\end{array}$ & 61 & $\begin{array}{l}\text { permissive referent group absence norms } \\
(+)\end{array}$ & \\
\hline (Barmby et al. 2001) & 2001 & Contracted Workdays and Absence & Cross-sectional & $\begin{array}{l}\text { Employees in manufacturing firm } \\
\text { operating production lines in UK }\end{array}$ & 13 & contracted workdays $(-)$ & \\
\hline (Bentley et al. 2012) & 2012 & $\begin{array}{l}\text { Perceptions of Workplace Bullying } \\
\text { in the New Zealand Travel } \\
\text { Industry: Prevalence and } \\
\text { Management Strategies }\end{array}$ & Cross-sectional & $\begin{array}{l}\text { Employees in retail and business } \\
\text { travel agencies and travel } \\
\text { wholesale companies in New } \\
\text { Zealand }\end{array}$ & 15 & workplace bullying $(+)$ & \\
\hline (Blau 1986) & 1986 & $\begin{array}{l}\text { Job Involvement and } \\
\text { Organizational Commitment as } \\
\text { Interactive Predictors of Tardiness } \\
\text { and Absenteeism }\end{array}$ & Cross-sectional & $\begin{array}{l}\text { Staff nurses working in a hospital } \\
\text { in the US }\end{array}$ & 89 & $\begin{array}{l}\text { work related attitudes: job involvement } \\
\text { and organizational commitment in } \\
\text { interaction }(-)\end{array}$ & \\
\hline $\begin{array}{l}\text { (Bolin and Heatherly } \\
\text { 2001) }\end{array}$ & 2001 & $\begin{array}{l}\text { Predictors of Employee Deviance: } \\
\text { The Relationship Between Bad } \\
\text { Attitudes and Bad Behavior }\end{array}$ & Cross-sectional & $\begin{array}{l}\text { Entry-level restaurant, } \\
\text { supermarket and grocery store } \\
\text { employees }\end{array}$ & 40 & $\begin{array}{l}\text { attitude variables (theft approval, intent to } \\
\text { quit, and dissatisfaction) }(+)\end{array}$ & \\
\hline
\end{tabular}


Table 1. Cont.

\begin{tabular}{|c|c|c|c|c|c|c|c|}
\hline Authors & Year & Title & Study Design & Study Population & Citations & $\begin{array}{l}\text { Determinants and Impact Direction } \\
\text { (Negative }(-) \text { or Positive }(+) \text { ) }\end{array}$ & Outcomes \\
\hline (Boon et al. 2014) & 2014 & $\begin{array}{l}\text { Perceived Human Resource } \\
\text { Management Practices: Their Effect } \\
\text { on Employee Absenteeism and } \\
\text { Time Allocation at Work }\end{array}$ & Cross-sectional & $\begin{array}{l}\text { Employees of the governmental } \\
\text { organization in Netherlands }\end{array}$ & 5 & $\begin{array}{l}\text { job satisfaction }(-) \\
\text { employee perception of HRM practices } \\
\text { (perceptions of the employment relation } \\
\text { bundle) (-) } \\
\text { HRM practices (people flow, appraisal } \\
\text { and reward, employment relation bundle: } \\
\text { mediated through job satisfaction) }(-)\end{array}$ & \\
\hline $\begin{array}{l}\text { (Brooke and Price } \\
\text { 1989) }\end{array}$ & 1989 & $\begin{array}{l}\text { The Determinants of Employee } \\
\text { Absenteeism: An Empirical Test of } \\
\text { a Causal Model }\end{array}$ & Cross-sectional & $\begin{array}{l}\text { Full-time employees in Veterans } \\
\text { Administration medical centre in } \\
\text { the US }\end{array}$ & 125 & $\begin{array}{l}\text { kinship responsibility, organizational } \\
\text { permissiveness, role ambiguity and alcohol } \\
\text { involvement }(+) \\
\text { centralization, pay and job satisfaction }(-)\end{array}$ & \\
\hline (Brown 1999) & 1999 & $\begin{array}{l}\text { Worker Absenteeism and Overtime } \\
\text { Bans }\end{array}$ & Longitudinal & $\begin{array}{l}\text { Employees of a manufacturing } \\
\text { company in Great Britain }\end{array}$ & 8 & $\begin{array}{l}\text { overtime bans }(+) \\
\text { gender (female) }(+) \\
\text { age (youngest and oldest) }(+) \\
\text { previous absence }(+) \\
\text { full-time contract }(-) \\
\text { wage }(-)\end{array}$ & \\
\hline (Butler et al. 1998) & 1998 & $\begin{array}{l}\text { More Than Cost Shifting: Moral } \\
\text { Hazard Lowers Productivity }\end{array}$ & Longitudinal & $\begin{array}{l}\text { Manufacturing industries in the } \\
\text { US }\end{array}$ & 11 & medical costs (price of health care) $(+)$ & \\
\hline $\begin{array}{l}\text { (Byron and Peterson } \\
\text { 2002) }\end{array}$ & 2002 & $\begin{array}{l}\text { The Impact of a Large-Scale } \\
\text { Traumatic Event on Individual and } \\
\text { Organizational Outcomes: } \\
\text { Exploring Employee and Company } \\
\text { Reactions to } 11 \text { September } 2001\end{array}$ & Cross-sectional & $\begin{array}{l}\text { Full-time employment MPA and } \\
\text { MBA students in the US }\end{array}$ & 40 & $\begin{array}{l}\text { strain from an acute-extraorganizational } \\
\text { stressor }(-)\end{array}$ & \\
\hline (Carmeli et al. 2007) & 2007 & $\begin{array}{l}\text { Considerations in Organizational } \\
\text { Career Advancement: What Really } \\
\text { Matters }\end{array}$ & Cross-sectional & $\begin{array}{l}\text { Employees working in both } \\
\text { service and non-service } \\
\text { organizations, operating in the } \\
\text { communication, electronics, } \\
\text { banking, insurance, car providers, } \\
\text { software, and advertisement } \\
\text { industries in Israel }\end{array}$ & 17 & & $\begin{array}{l}\text { career mobility } \\
(+)\end{array}$ \\
\hline (Chullen et al. 2010) & 2010 & $\begin{array}{l}\text { Minimizing Deviant Behavior in } \\
\text { Healthcare Organizations: The } \\
\text { Effects of Supportive Leadership } \\
\text { and Job Design }\end{array}$ & Cross-sectional & $\begin{array}{l}\text { Employees of a healthcare } \\
\text { organization in the US }\end{array}$ & 12 & $\begin{array}{l}\text { perceived organizational support and } \\
\text { intrinsic motivation }(-)\end{array}$ & \\
\hline
\end{tabular}


Table 1. Cont.

\begin{tabular}{|c|c|c|c|c|c|c|c|}
\hline Authors & Year & Title & Study Design & Study Population & Citations & $\begin{array}{l}\text { Determinants and Impact Direction } \\
\text { (Negative }(-) \text { or Positive }(+))\end{array}$ & Outcomes \\
\hline $\begin{array}{l}\text { (Chung and Schneider } \\
\text { 2002) }\end{array}$ & 2002 & $\begin{array}{l}\text { Serving Multiple Masters: Role } \\
\text { Conflict Experienced by Service } \\
\text { Employees }\end{array}$ & Cross-sectional & $\begin{array}{l}\text { Telephone service employees in } \\
\text { an insurance company in the US }\end{array}$ & 79 & role conflict $(+)$ & \\
\hline (Cohen 1998) & 1998 & $\begin{array}{l}\text { An Examination of the Relationship } \\
\text { Between Work Commitment and } \\
\text { Work Outcomes Among Hospital } \\
\text { Nurses }\end{array}$ & Cross-sectional & Hospital nurses in Canada & 36 & job involvement $(-)$ & \\
\hline $\begin{array}{l}\text { (Cohen and Golan } \\
\text { 2007) }\end{array}$ & 2007 & $\begin{array}{l}\text { Predicting Absenteeism and } \\
\text { Turnover Intentions by Past } \\
\text { Absenteeism and Work Attitudes: } \\
\text { An Empirical Examination of } \\
\text { Female Employees in Long Term } \\
\text { Nursing Care Facilities }\end{array}$ & Cross-sectional & $\begin{array}{l}\text { Employees of long term nursing } \\
\text { care facilities in Israel }\end{array}$ & 44 & $\begin{array}{l}\text { prior absenteeism }(+) \\
\text { job satisfaction }(-)\end{array}$ & \\
\hline (Colquitt et al. 2002) & 2002 & $\begin{array}{l}\text { Justice in Teams: Antecedents and } \\
\text { Consequences of Procedural Justice } \\
\text { Climate }\end{array}$ & Cross-sectional & $\begin{array}{l}\text { Employees working in teams in } \\
\text { automobile parts manufacturing } \\
\text { firm in the US }\end{array}$ & 322 & $\begin{array}{l}\text { climate level (i.e., the average procedural } \\
\text { justice perception within the team) }(-)\end{array}$ & \\
\hline $\begin{array}{l}\text { (Cornelissen et al. } \\
\text { 2013) }\end{array}$ & 2013 & $\begin{array}{l}\text { Fairness Spillovers-The Case of } \\
\text { Taxation }\end{array}$ & Longitudinal & Households in Germany & 5 & $\begin{array}{l}\text { self-perceived level of well-being }(-) \\
\text { perceived unfairness } \\
\text { in taxing the rich }(-) \\
\text { tenure }(+) \\
\text { firm size }(+)\end{array}$ & \\
\hline (Dasgupta et al. 2012) & 2012 & $\begin{array}{l}\text { Impact of Managerial } \\
\text { Communication Styles on } \\
\text { Employees' Attitudes and } \\
\text { Behaviours }\end{array}$ & Cross-sectional & $\begin{array}{l}\text { Full-time employees in } \\
\text { manufacturing organisations in } \\
\text { India }\end{array}$ & 11 & emotional bond with organizations (-) & \\
\hline (De Boer et al. 2002) & 2002 & $\begin{array}{l}\text { Unfairness at Work as a Predictor } \\
\text { of Absenteeism }\end{array}$ & Cross-sectional & $\begin{array}{l}\text { Male employees in a security firm } \\
\text { in Belgium }\end{array}$ & 101 & $\begin{array}{l}\text { distributive unfairness }(+) \\
\text { procedural unfairness (under the } \\
\text { mediating effect of affective commitment) } \\
(+)\end{array}$ & \\
\hline
\end{tabular}


Table 1. Cont.

\begin{tabular}{|c|c|c|c|c|c|c|c|}
\hline Authors & Year & Title & Study Design & Study Population & Citations & $\begin{array}{l}\text { Determinants and Impact Direction } \\
\text { (Negative }(-) \text { or Positive }(+))\end{array}$ & Outcomes \\
\hline (Deery et al. 1995) & 1995 & $\begin{array}{l}\text { The Determinants of Absenteeism: } \\
\text { Evidence from Australian } \\
\text { Blue-Collar Employees }\end{array}$ & Cross-sectional & $\begin{array}{l}\text { Employees in a motor-vehicle } \\
\text { company in Australia }\end{array}$ & 10 & $\begin{array}{l}\text { accumulated sick pay }(-) \\
\text { job motivation }(-) \\
\text { external responsibilities (greater family } \\
\text { and personal obligations) }(+) \\
\text { routinization (mediated through job } \\
\text { motivation) }(+) \\
\text { absence culture (mediated through job } \\
\text { motivation) }(-) \\
\text { supervisory support (mediated through } \\
\text { job motivation) }(-) \\
\text { previous disciplinary warnings }(-) \\
\text { accumulation of sick pay }(-)\end{array}$ & \\
\hline $\begin{array}{l}\text { (Deery and Iverson } \\
\text { 2005) }\end{array}$ & 2005 & $\begin{array}{l}\text { Labor-Management Cooperation: } \\
\text { Antecedents and Impact on } \\
\text { Organizational Performance }\end{array}$ & Longitudinal & $\begin{array}{l}\text { International bank employees } \\
\text { in Australia }\end{array}$ & 56 & union loyalty $(-)$ & \\
\hline (Deery et al. 2014) & 2014 & $\begin{array}{l}\text { Can Union Voice Make a } \\
\text { Difference? The Effect of Union } \\
\text { Citizenship Behavior on Employee } \\
\text { Absence }\end{array}$ & Longitudinal & $\begin{array}{l}\text { International bank employees } \\
\text { in Australia }\end{array}$ & 4 & $\begin{array}{l}\text { union citizenship behavior (helping fellow } \\
\text { members with workplace grievances) }(-)\end{array}$ & \\
\hline (Dehue et al. 2012) & 2012 & $\begin{array}{l}\text { Coping with Bullying at Work and } \\
\text { Health Related Problems }\end{array}$ & Cross-sectional & $\begin{array}{l}\text { Residents who work at least eight } \\
\text { hours a week in any organization } \\
\text { in the Netherlands where they } \\
\text { have both colleagues and a } \\
\text { manager }\end{array}$ & 20 & bullying (+) & \\
\hline $\begin{array}{l}\text { (Diestel and Schmidt } \\
\text { 2012) }\end{array}$ & 2012 & $\begin{array}{l}\text { Lagged Mediator Effects of } \\
\text { Self-Control Demands on } \\
\text { Psychological Strain and } \\
\text { Absenteeism }\end{array}$ & Longitudinal & $\begin{array}{l}\text { Employees in a health insurance } \\
\text { company and a financial service } \\
\text { institution in Germany }\end{array}$ & 20 & $\begin{array}{l}\text { workload (mediated through self-control } \\
\text { demands) }(+)\end{array}$ & \\
\hline $\begin{array}{l}\text { (Dionne and Dostie } \\
\text { 2007) }\end{array}$ & 2007 & $\begin{array}{l}\text { New Evidence on the Determinants } \\
\text { of Absenteeism Using Linked } \\
\text { Employer-Employee Data }\end{array}$ & Longitudinal & $\begin{array}{l}\text { Establishments and their workers } \\
\text { in Canada }\end{array}$ & 48 & $\begin{array}{l}\text { work arrangements: } \\
\text { standard weekday work hours, } \\
\text { work-at-home options, and reduced work } \\
\text { weeks }(-) \\
\text { shift work and compressed work weeks (+) }\end{array}$ & \\
\hline $\begin{array}{l}\text { (Drakopoulos and } \\
\text { Grimani 2013) }\end{array}$ & 2013 & $\begin{array}{l}\text { Injury-Related Absenteeism and } \\
\text { Job Satisfaction: Insights from } \\
\text { Greek and UK Data }\end{array}$ & Cross-sectional & Individuals in Greece and the UK & 3 & job satisfaction $(-)$ & \\
\hline
\end{tabular}


Table 1. Cont.

\begin{tabular}{|c|c|c|c|c|c|c|c|}
\hline Authors & Year & Title & Study Design & Study Population & Citations & $\begin{array}{l}\text { Determinants and Impact Direction } \\
\text { (Negative }(-) \text { or Positive }(+))\end{array}$ & Outcomes \\
\hline $\begin{array}{l}\text { (Farrell and Petersen } \\
\text { 1984) }\end{array}$ & 1984 & $\begin{array}{l}\text { Commitment, Absenteeism, and } \\
\text { Turnover of New Employees: A } \\
\text { Longitudinal Study }\end{array}$ & Longitudinal & Nurses and accountants in the US & 31 & commitment (-) & turnover $(+)$ \\
\hline (Festing et al. 1999) & 1999 & $\begin{array}{l}\text { Financial Participation in } \\
\text { Europe-Determinants and } \\
\text { Outcomes }\end{array}$ & Cross-sectional & HMR managers & 31 & profit sharing $(-)$ & \\
\hline (Frick and Malo 2008) & 2008 & $\begin{array}{l}\text { Labor Market Institutions and } \\
\text { Individual Absenteeism in the } \\
\text { European Union: The Relative } \\
\text { Importance of Sickness Benefit } \\
\text { Systems and Employment } \\
\text { Protection Legislation }\end{array}$ & Cross-sectional & Employees and self-employed & 30 & sickness benefits $(+)$ & \\
\hline (Frooman et al. 2012) & 2012 & $\begin{array}{l}\text { Transformational and Passive } \\
\text { Avoidant Leadership as } \\
\text { Determinants of Absenteeism }\end{array}$ & Cross-sectional & $\begin{array}{l}\text { Establishments and their workers } \\
\text { in Canada }\end{array}$ & 3 & $\begin{array}{l}\text { to illegitimate: transformational leadership } \\
(-) \\
\text { passive avoidant leadership }(+) \\
\text { to legitimate: passive avoidant leadership } \\
(-)\end{array}$ & \\
\hline (Fugate et al. 2012) & 2012 & $\begin{array}{l}\text { Managing Employee Withdrawal } \\
\text { During Organizational Change: } \\
\text { The Role of Threat Appraisal }\end{array}$ & Cross-sectional & Individuals in Greece and the UK & 48 & threat appraisals $(+)$ & \\
\hline (Garcia 1987) & 1987 & $\begin{array}{l}\text { Sick-Time Usage by Management } \\
\text { and Professional Employees in the } \\
\text { Public Sector }\end{array}$ & Cross-sectional & Nurses and accountants in the US & 6 & $\begin{array}{l}\text { age }(+) \\
\text { gender (woman) }(+) \\
\text { race and ethnic (minorities) }(+) \\
\text { education }(-) \\
\text { marital status }(+) \\
\text { tenure }(-) \\
\text { job level }(-) \\
\text { contact arrangements (flex-time and } \\
\text { compressed work weeks vs. fixed } \\
\text { schedule) }(+)\end{array}$ & \\
\hline
\end{tabular}


Table 1. Cont.

\begin{tabular}{|c|c|c|c|c|c|c|c|}
\hline Authors & Year & Title & Study Design & Study Population & Citations & $\begin{array}{l}\text { Determinants and Impact Direction } \\
\text { (Negative }(-) \text { or Positive }(+))\end{array}$ & Outcomes \\
\hline $\begin{array}{l}\text { (Garrison and } \\
\text { Muchinsky 1977) }\end{array}$ & 1977 & $\begin{array}{l}\text { Attitudinal and Biographical } \\
\text { Predictors of Incidental } \\
\text { Absenteeism }\end{array}$ & Cross-sectional & $\begin{array}{l}\text { Accounting department } \\
\text { employees in the US }\end{array}$ & 20 & $\begin{array}{l}\text { for unpaid absence: satisfaction with work } \\
(-) \\
\text { overall job satisfaction }(-) \\
\text { age }(-) \\
\text { tenure }(-) \\
\text { for paid absence: } \\
\text { age }(+) \\
\text { tenure }(+)\end{array}$ & \\
\hline (Gellatly 1995) & 1995 & $\begin{array}{l}\text { Individual and Group } \\
\text { Determinants of Employee } \\
\text { Absenteeism: Test of a Causal } \\
\text { Model }\end{array}$ & Cross-sectional & $\begin{array}{l}\text { Nursing and food services } \\
\text { employees in a mid-size chronic } \\
\text { care hospital in Canada }\end{array}$ & 121 & $\begin{array}{l}\text { individual and group-level factors: } \\
\text { tenure }(+) \\
\text { age }(-) \\
\text { affective commitment }(-) \\
\text { continuous commitment }(+) \\
\text { interactional justice (supervisor) }(-) \\
\text { perceived absence norm }(+)\end{array}$ & \\
\hline $\begin{array}{l}\text { (Gellatly and Luchak } \\
\text { 1998) }\end{array}$ & 1998 & $\begin{array}{l}\text { Personal and Organizational } \\
\text { Determinants of Perceived Absence } \\
\text { Norms }\end{array}$ & Cross-sectional & Hospital employees in Canada & 6 & $\begin{array}{l}\text { perceived absence norms (to future } \\
\text { absence) }(+)\end{array}$ & $\begin{array}{l}\text { employees' } \\
\text { normative } \\
\text { perceptions } \\
\text { (influenced by } \\
\text { their prior } \\
\text { personal absence } \\
\text { and by the } \\
\text { average level of } \\
\text { absence within } \\
\text { both their } \\
\text { immediate work } \\
\text { group and the } \\
\text { absence culture } \\
\text { to which they } \\
\text { belonged) }\end{array}$ \\
\hline (Gerstenfeld 1969) & 1969 & $\begin{array}{l}\text { Employee Absenteeism: New } \\
\text { Insights: Data Reveal External } \\
\text { Factors }\end{array}$ & Cross-sectional & $\begin{array}{l}\text { Laundry and drycleaning } \\
\text { industry employees in the US }\end{array}$ & 5 & $\begin{array}{l}\text { fairness of the immediate supervisor }(-) \\
\text { working conditions }(-) \\
\text { age }(-) \\
\text { child care }(-)\end{array}$ & \\
\hline $\begin{array}{l}\text { (Goldberg and } \\
\text { Waldman 2000) }\end{array}$ & 2000 & $\begin{array}{l}\text { Modelling Employee Absenteeism: } \\
\text { Testing Alternative Measures and } \\
\text { Mediated Effects Based on Job } \\
\text { Satisfaction }\end{array}$ & Cross-sectional & Hospital employees in the US & 45 & $\begin{array}{l}\text { job satisfaction (unrelated to absenteeism) } \\
\text { wage }(-) \\
\text { health }(-)\end{array}$ & \\
\hline
\end{tabular}


Table 1. Cont.

\begin{tabular}{|c|c|c|c|c|c|c|c|}
\hline Authors & Year & Title & Study Design & Study Population & Citations & $\begin{array}{l}\text { Determinants and Impact Direction } \\
\text { (Negative }(-) \text { or Positive }(+))\end{array}$ & Outcomes \\
\hline (Hassan et al. 2014) & 2014 & $\begin{array}{l}\text { Does Ethical Leadership Matter in } \\
\text { Government? Effects on } \\
\text { Organizational Commitment, } \\
\text { Absenteeism, and Willingness to } \\
\text { Report Ethical Problems }\end{array}$ & Cross-sectional & $\begin{array}{l}\text { Employees of a state government } \\
\text { agency in the US }\end{array}$ & 20 & ethical leadership (-) & \\
\hline (Hattrup et al. 1998) & 1998 & $\begin{array}{l}\text { Prediction of Multidimensional } \\
\text { Criteria: Distinguishing Task and } \\
\text { Contextual Performance }\end{array}$ & Cross-sectional & $\begin{array}{l}\text { Entry-level customer service and } \\
\text { sales representatives from several } \\
\text { stores of a retail chain in Mexico }\end{array}$ & 62 & conscientiousness $(-)$ & $\begin{array}{l}\text { organizational } \\
\text { citizenship } \\
\text { behavior }\end{array}$ \\
\hline $\begin{array}{l}\text { (Hausknecht et al. } \\
\text { 2008) }\end{array}$ & 2008 & $\begin{array}{l}\text { Work-Unit Absenteeism: Effects of } \\
\text { Satisfaction, Commitment, Labor } \\
\text { Market Conditions, and Time }\end{array}$ & Longitudinal & $\begin{array}{l}\text { Employees in a State department } \\
\text { of transportation in the US }\end{array}$ & 59 & $\begin{array}{l}\text { shared (group) job satisfaction and } \\
\text { organizational commitment in interactions } \\
(-) \\
\text { unit-level job satisfaction and } \\
\text { organizational commitment }(-)\end{array}$ & \\
\hline $\begin{array}{l}\text { (Hemingway and } \\
\text { Smith 1999) }\end{array}$ & 1999 & $\begin{array}{l}\text { Organizational Climate and } \\
\text { Occupational Stressors as } \\
\text { Predictors of Withdrawal } \\
\text { Behaviours and Injuries in Nurses }\end{array}$ & Cross-sectional & Hospital nurses in Canada & 136 & $\begin{array}{l}\text { Organizational climate dimensions (have } \\
\text { no effect on absenteeism) }\end{array}$ & \\
\hline $\begin{array}{l}\text { (Herrmann and } \\
\text { Rockoff 2012) }\end{array}$ & 2012 & $\begin{array}{l}\text { Worker Absence and Productivity: } \\
\text { Evidence from Teaching }\end{array}$ & Cross-sectional & Teachers in the US & 14 & & productivity $(-)$ \\
\hline $\begin{array}{l}\text { (Ichino and Riphahn } \\
\text { 2005) }\end{array}$ & 2005 & $\begin{array}{l}\text { The Effect of Employment } \\
\text { Protection on Worker Effort: } \\
\text { Absenteeism During and After } \\
\text { Probation }\end{array}$ & Longitudinal & Bank employees in Italy & 122 & employment protection $(-)$ & \\
\hline (Ivancevich 1986) & 1986 & $\begin{array}{l}\text { Life Events and Hassles as } \\
\text { Predictors of Health Symptoms, Job } \\
\text { Performance, and Absenteeism }\end{array}$ & Cross-sectional & $\begin{array}{l}\text { Assembly line employees from a } \\
\text { medium-sized non-union } \\
\text { manufacturing corporation in the } \\
\text { US }\end{array}$ & 46 & hassel daily uplifts (-) & \\
\hline $\begin{array}{l}\text { (Iverson and Buttigieg } \\
\text { 1999) }\end{array}$ & 1999 & $\begin{array}{l}\text { Affective, Normative and } \\
\text { Continuance Commitment: Can the } \\
\text { 'Right Kind' of Commitment Be } \\
\text { Managed? }\end{array}$ & Cross-sectional & $\begin{array}{l}\text { Fire fighting and rescue service } \\
\text { employees in Australia }\end{array}$ & 135 & affective and normative commitment $(-)$ & \\
\hline (Iverson et al. 1998) & 1998 & $\begin{array}{l}\text { Affectivity, Organizational } \\
\text { Stressors, and Absenteeism: A } \\
\text { Causal Model of Burnout and Its } \\
\text { Consequences }\end{array}$ & Cross-sectional & Public hospital employees & 160 & $\begin{array}{l}\text { high role stress (+) } \\
\text { high personal accomplishment, workload, } \\
\text { peer support, co-worker } \\
\text { support, personal affectivity, autonomy } \\
\text { and supervisory support (-) }\end{array}$ & \\
\hline
\end{tabular}


Table 1. Cont.

\begin{tabular}{|c|c|c|c|c|c|c|c|}
\hline Authors & Year & Title & Study Design & Study Population & Citations & $\begin{array}{l}\text { Determinants and Impact Direction } \\
\text { (Negative }(-) \text { or Positive }(+) \text { ) }\end{array}$ & Outcomes \\
\hline $\begin{array}{l}\text { (Johnson and } \\
\text { O'Leary-Kelly 2003) }\end{array}$ & 2003 & $\begin{array}{l}\text { The Effects of Psychological } \\
\text { Contract Breach and } \\
\text { Organizational Cynicism: Not All } \\
\text { Social Exchange Violations are } \\
\text { Created Equal }\end{array}$ & Cross-sectional & Bank employees in the US & 221 & psychological contract breach $(+)$ & \\
\hline (Johnson et al. 2014) & 2014 & $\begin{array}{l}\text { Outcomes of Absence Control } \\
\text { Initiatives: A Quasi-Experimental } \\
\text { Investigation into the Effects of } \\
\text { Policy and Perceptions }\end{array}$ & $\begin{array}{l}\text { Quasi-experimental } \\
\text { (pre-test-post-test } \\
\text { without control } \\
\text { group) }\end{array}$ & $\begin{array}{l}\text { Employees in two plants of a } \\
\text { large unionized automobile parts } \\
\text { manufacturer in the US }\end{array}$ & 5 & $\begin{array}{l}\text { absence policy change (-) (for casual } \\
\text { absence) } \\
(+) \text { (for family and medical leave act } \\
\text { absence) }\end{array}$ & \\
\hline (Jones et al. 2009) & 2009 & $\begin{array}{l}\text { Comparative Effects of } \\
\text { Race/Ethnicity and Employee } \\
\text { Engagement on Withdrawal } \\
\text { Behavior }\end{array}$ & Cross-sectional & Employees in the US & 13 & employee engagement (-) & \\
\hline $\begin{array}{l}\text { (Judge and } \\
\text { Martocchio 1996) }\end{array}$ & 1996 & $\begin{array}{l}\text { Dispositional Influences on } \\
\text { Attributions Concerning } \\
\text { Absenteeism }\end{array}$ & Mixed method & University employees in the US & 23 & $\begin{array}{l}\text { personal illness }(+) \\
\text { presence of kinship responsibilities }(+)\end{array}$ & \\
\hline $\begin{array}{l}\text { (Jung and Takeuchi } \\
\text { 2010) }\end{array}$ & 2010 & $\begin{array}{l}\text { Performance Implications for the } \\
\text { Relationships among Top } \\
\text { Management Leadership, } \\
\text { Organizational Culture, and } \\
\text { Appraisal Practice: Testing Two } \\
\text { Theory-Based Models of } \\
\text { Organizational Learning Theory in } \\
\text { Japan }\end{array}$ & Cross-sectional & $\begin{array}{l}\text { SMEs in the manufacturing sector } \\
\text { in Japan }\end{array}$ & 12 & supportive leadership (-) & $\begin{array}{l}\text { workforce } \\
\text { productivity (-) }\end{array}$ \\
\hline $\begin{array}{l}\text { (Kim and Garman } \\
\text { 2003) }\end{array}$ & 2003 & $\begin{array}{l}\text { Financial Stress and Absenteeism: } \\
\text { An Empirically Derived Model }\end{array}$ & $\begin{array}{l}\text { Quasi-experimental } \\
\text { (pre-test-post-test } \\
\text { without control } \\
\text { group) }\end{array}$ & $\begin{array}{l}\text { White-collar workers of an } \\
\text { insurance company in the US }\end{array}$ & 23 & financial stress (+) & \\
\hline (Kolz 1999) & 1999 & $\begin{array}{l}\text { Personality Predictors of Retail } \\
\text { Employee Theft and } \\
\text { Counterproductive Behavior }\end{array}$ & Quasi-experimental & $\begin{array}{l}\text { Employees working for a } \\
\text { women's apparel retailer with } \\
\text { several stores in the New York } \\
\text { City area in the US }\end{array}$ & 13 & $\begin{array}{l}\text { personality: } \\
\text { conscientiousness, } \\
\text { agreeableness }\end{array}$ & \\
\hline $\begin{array}{l}\text { (Kopelman and } \\
\text { Schneller 1981) }\end{array}$ & 1981 & $\begin{array}{l}\text { A Mixed-Consequence System for } \\
\text { Reducing Overtime and } \\
\text { Unscheduled Absences }\end{array}$ & $\begin{array}{l}\text { Quasi-experimental } \\
\text { (pre-test-post-test } \\
\text { without control } \\
\text { group) }\end{array}$ & $\begin{array}{l}\text { Employees of a 220-bed } \\
\text { proprietary medical center in the } \\
\text { US }\end{array}$ & 15 & $\begin{array}{l}\text { mixed consequence control system } \\
\text { (punishment and rewards) }(-)\end{array}$ & $\begin{array}{l}\text { operational } \\
\text { efficiency }(-)\end{array}$ \\
\hline
\end{tabular}


Table 1. Cont.

\begin{tabular}{|c|c|c|c|c|c|c|c|}
\hline Authors & Year & Title & Study Design & Study Population & Citations & $\begin{array}{l}\text { Determinants and Impact Direction } \\
\text { (Negative }(-) \text { or Positive }(+))\end{array}$ & Outcomes \\
\hline (Krausz et al. 1998) & 1998 & $\begin{array}{l}\text { Distal and Proximal Influences on } \\
\text { Turnover Intentions and } \\
\text { Satisfaction: Support for a } \\
\text { Withdrawal Progression Theory }\end{array}$ & $\begin{array}{l}\text { Quasi-experimental } \\
\text { (pre-test without } \\
\text { control group) }\end{array}$ & $\begin{array}{l}\text { Non-academic employees of a } \\
\text { large academic institution in } \\
\text { Israel }\end{array}$ & 20 & & $\begin{array}{l}\text { satisfaction }(-) \\
\text { intention to } \\
\text { leave }(+)\end{array}$ \\
\hline (Kristensen et al. 2006) & 2006 & $\begin{array}{l}\text { Determinants of Absenteeism in a } \\
\text { Large Danish Bank }\end{array}$ & Cross-sectional & $\begin{array}{l}\text { The study is based on } \\
\text { information from approx. 7,000 } \\
\text { employees in } 500 \text { different bank } \\
\text { units in Denmark }\end{array}$ & 18 & job satisfaction $(-)$ & \\
\hline $\begin{array}{l}\text { (Landeweerd and } \\
\text { Boumans 1994) }\end{array}$ & 1994 & $\begin{array}{l}\text { The Effect of Work Dimensions and } \\
\text { Need for Autonomy on Nurses' } \\
\text { Work Satisfaction and Health }\end{array}$ & Cross-sectional & $\begin{array}{l}\text { Nurses in } 16 \text { randomly chosen } \\
\text { hospitals in the Netherlands }\end{array}$ & 80 & $\begin{array}{l}\text { preference to autonomy (moderating effect } \\
\text { of the presence of autonomy) }(-) \\
\text { traditional task-oriented nursing care } \\
\text { system (moderating effect of the preference } \\
\text { for autonomy) }(+)\end{array}$ & \\
\hline $\begin{array}{l}\text { (Leśniowska et al. } \\
\text { 2014) }\end{array}$ & 2014 & $\begin{array}{l}\text { Costs of Diabetes and Its } \\
\text { Complications in Poland }\end{array}$ & Cross-sectional & $\begin{array}{l}\text { Data acquired from the National } \\
\text { Health Fund (NFZ), ZUS (Social } \\
\text { Insurance Institution), and from } \\
\text { GUS (Poland's Central Statistical } \\
\text { Office) in Poland }\end{array}$ & 14 & diabetes mellitus $(\mathrm{dm})(-)$ & \\
\hline (Løkke Nielsen 2008) & 2008 & $\begin{array}{l}\text { Determinants of Absenteeism in } \\
\text { Public Organizations: A Unit-Level } \\
\text { Analysis of Work Absence in a } \\
\text { Large Danish Municipality }\end{array}$ & Cross-sectional & $\begin{array}{l}\text { Data from approximately } 5,000 \\
\text { employees in } 400 \text { departments of } \\
\text { day-care centres in Denmark }\end{array}$ & 12 & $\begin{array}{l}\text { age }(-) \\
\text { deputy head gender (woman) }(-) \\
\text { deputy head's absence }(+)\end{array}$ & \\
\hline $\begin{array}{l}\text { (Mason and Griffin } \\
\text { 2003) }\end{array}$ & 2003 & $\begin{array}{l}\text { Group Absenteeism and Positive } \\
\text { Affective Tone: A Longitudinal } \\
\text { Study }\end{array}$ & Longitudinal & $\begin{array}{l}\text { State government agency } \\
\text { employees in Australia }\end{array}$ & 46 & positive affective tone $(-)$ & \\
\hline (Mchugh 2002) & 2002 & $\begin{array}{l}\text { The Absence Bug: A Treatable Viral } \\
\text { Infection? }\end{array}$ & Cross-sectional & $\begin{array}{l}\text { Employees in local government } \\
\text { organisations in Ireland }\end{array}$ & 10 & & $\begin{array}{l}\text { organizational } \\
\text { health } \\
\text { (employee } \\
\text { morale, stress } \\
\text { level, quality } \\
\text { communication } \\
\text { processes, } \\
\text { satisfaction) (-) }\end{array}$ \\
\hline (Morrow et al. 1999) & 1999 & $\begin{array}{l}\text { Using Absenteeism and } \\
\text { Performance to Predict Employee } \\
\text { Turnover: Early Detection Through } \\
\text { Company Records }\end{array}$ & Cross-sectional & $\begin{array}{l}\text { Data from the personal files of life } \\
\text { insurance company employees in } \\
\text { the US }\end{array}$ & 24 & & $\begin{array}{l}\text { voluntary } \\
\text { turnover }(+)\end{array}$ \\
\hline
\end{tabular}


Table 1. Cont.

\begin{tabular}{|c|c|c|c|c|c|c|c|}
\hline Authors & Year & Title & Study Design & Study Population & Citations & $\begin{array}{l}\text { Determinants and Impact Direction } \\
\quad \text { (Negative }(-) \text { or Positive }(+))\end{array}$ & Outcomes \\
\hline (Moscarola et al. 2016) & 2016 & $\begin{array}{l}\text { Absenteeism, Childcare and the } \\
\text { Effectiveness of Pension Reforms }\end{array}$ & Cross-sectional & $\begin{array}{l}\text { Women registered in the } \\
\text { private-sector employees' scheme } \\
\text { in Italy }\end{array}$ & 3 & $\begin{array}{l}\text { governmental postponement of retirement } \\
\text { and poor supply of childcare services (-) }\end{array}$ & \\
\hline $\begin{array}{l}\text { (Mukhopadhyay et al. } \\
\text { 1997) }\end{array}$ & 1997 & $\begin{array}{l}\text { Information Technology Impact on } \\
\text { Process Output and Quality }\end{array}$ & Cross-sectional & $\begin{array}{l}\text { Data from } 46 \text { mail processing } \\
\text { centres in the US }\end{array}$ & 142 & & $\begin{array}{l}\text { quality and } \\
\text { output (-) }\end{array}$ \\
\hline (Nguyen et al. 2016) & 2016 & $\begin{array}{l}\text { When the Going Gets Tough, the } \\
\text { Tough Keep Working: Impact of } \\
\text { Emotional Labor on Absenteeism }\end{array}$ & Cross-sectional & $\begin{array}{l}\text { Public hospital nurses in } \\
\text { Australia }\end{array}$ & 5 & emotional labor: surface acting $(+)$ & \\
\hline (Nicholson et al. 1978) & 1978 & $\begin{array}{l}\text { Shiftwork and Absence: An } \\
\text { Analysis of Temporal Trends }\end{array}$ & Cross-sectional & $\begin{array}{l}250 \text { male maintenance engineers } \\
\text { attached to several production } \\
\text { and ancillary departments of a } \\
\text { large steelworks in the UK }\end{array}$ & 18 & $\begin{array}{l}\text { shiftwork: shift-turn, days of the week, } \\
\text { position in the shift cycle }\end{array}$ & \\
\hline (Orpen 1979) & 1979 & $\begin{array}{l}\text { The Effects of Job Enrichment on } \\
\text { Employee Satisfaction, Motivation, } \\
\text { Involvement, and Performance: A } \\
\text { Field Experiment }\end{array}$ & $\begin{array}{l}\text { Quasi-experimental } \\
\text { (pre-test-post-test } \\
\text { with control } \\
\text { group) }\end{array}$ & $\begin{array}{l}\text { Local government agency } \\
\text { employees in South Africa }\end{array}$ & 66 & job enrichment $(-)$ & \\
\hline (Parasuraman 1982) & 1982 & $\begin{array}{l}\text { Predicting Turnover Intentions and } \\
\text { Turnover Behavior: A Multivariate } \\
\text { Analysis }\end{array}$ & Cross-sectional & $\begin{array}{l}\text { Non-supervisory plant workers } \\
\text { in a mediumsized food } \\
\text { processing company in the US }\end{array}$ & 94 & & turnover $(+)$ \\
\hline $\begin{array}{l}\text { (Pizam and } \\
\text { Thornburg 2000) }\end{array}$ & 2000 & $\begin{array}{l}\text { Absenteeism and Voluntary } \\
\text { Turnover in Central Florida Hotels: } \\
\text { A Pilot Study }\end{array}$ & Cross-sectional & $\begin{array}{l}\text { Hotel human resources managers } \\
\text { in the US }\end{array}$ & 51 & $\begin{array}{l}\text { work-related factors: morale, satisfaction } \\
\text { with compensation and benefits, fulfilment } \\
\text { of job expectations, level of pay, and } \\
\text { training }(-) \\
\text { personal characteristics: parenthood status } \\
(+)\end{array}$ & \\
\hline (Price 1998) & 1998 & $\begin{array}{l}\text { Estimation of Causal Model of } \\
\text { Absenteeism }\end{array}$ & Cross-sectional & Hospital employees in the US & 6 & $\begin{array}{l}\text { kinship responsibility, organizational } \\
\text { permissiveness, pay and supervisory } \\
\text { support }\end{array}$ & \\
\hline (Punnett et al. 2007) & 2007 & $\begin{array}{l}\text { Job Attitudes and Absenteeism: A } \\
\text { Study in the English Speaking } \\
\text { Caribbean }\end{array}$ & Cross-sectional & $\begin{array}{l}\text { Employees in } 5 \text { manufacturing } \\
\text { companies in Barbados }\end{array}$ & 27 & $\begin{array}{l}\text { employee's levels of satisfaction with } \\
\text { co-workers, activity, responsibility, and job } \\
\text { security, loyalty to the organization }\end{array}$ & \\
\hline
\end{tabular}


Table 1. Cont.

\begin{tabular}{|c|c|c|c|c|c|c|c|}
\hline Authors & Year & Title & Study Design & Study Population & Citations & $\begin{array}{l}\text { Determinants and Impact Direction } \\
\text { (Negative }(-) \text { or Positive }(+))\end{array}$ & Outcomes \\
\hline (Qin and Jiang 2011) & 2011 & $\begin{array}{l}\text { The Impact of Natural Disaster on } \\
\text { Absenteeism, Job Satisfaction, and } \\
\text { Job Performance of Survival } \\
\text { Employees: An Empirical Study of } \\
\text { the Survivors in Wenchuan } \\
\text { Earthquake }\end{array}$ & Mixed method & $\begin{array}{l}\text { Survival employees of } \\
\text { earthquake-affected enterprises } \\
\text { in China }\end{array}$ & 4 & earthquake (-) & \\
\hline (Redman et al. 2011) & 2011 & $\begin{array}{l}\text { Working Here Makes Me Sick! The } \\
\text { Consequences of Sick Building } \\
\text { Syndrome }\end{array}$ & Cross-sectional & $\begin{array}{l}\text { Police officers working in } \\
\text { air-conditioned buildings in the } \\
\text { Caribbean region }\end{array}$ & 6 & $\begin{array}{l}\text { sick building syndrome }(+) \\
\text { age }(-)\end{array}$ & \\
\hline $\begin{array}{l}\text { (Rentsch and Steel } \\
\text { 1998) }\end{array}$ & 1998 & $\begin{array}{l}\text { Testing the Durability of Job } \\
\text { Characteristics as Predictors of } \\
\text { Absenteeism Over a Six-Year } \\
\text { Period }\end{array}$ & Longitudinal & $\begin{array}{l}\text { Civilian employees from a large } \\
\text { military organization in the US }\end{array}$ & 49 & $\begin{array}{l}\text { individual job characteristics: skill variety, } \\
\text { task identity, autonomy (-) }\end{array}$ & \\
\hline $\begin{array}{l}\text { (Rred and Fevang } \\
\text { 2007) }\end{array}$ & 2007 & $\begin{array}{l}\text { Organizational Change, } \\
\text { Absenteeism, and Welfare } \\
\text { Dependency }\end{array}$ & Longitudinal & $\begin{array}{l}\text { Nurses in Norway employed by a } \\
\text { municipality or county who did } \\
\text { not receive any form of public } \\
\text { income support by the end of } \\
\text { October } 1992 \text { and who were } \\
\text { below } 53 \text { years of age at that time }\end{array}$ & 31 & downsizing processes $(+)$ & \\
\hline $\begin{array}{l}\text { (Rosse and Hulin } \\
\text { 1985) }\end{array}$ & 1985 & $\begin{array}{l}\text { Adaptation to Work: An Analysis } \\
\text { of Employee Health, Withdrawal, } \\
\text { and Change }\end{array}$ & Longitudinal & Hospital employees in the US & 100 & job satisfaction $(-)$ & \\
\hline (Saxton et al. 1991) & 1991 & $\begin{array}{l}\text { Antecedents and Consequences of } \\
\text { Emotional Exhaustion in the } \\
\text { Airline Reservations Service Sector }\end{array}$ & Cross-sectional & $\begin{array}{l}\text { Employees in the reservation } \\
\text { department of an airline } \\
\text { company in the US }\end{array}$ & 37 & emotional exhaustion (+) & \\
\hline (Scoppa 2010) & 2010 & $\begin{array}{l}\text { Worker Absenteeism and } \\
\text { Incentives: Evidence from Italy }\end{array}$ & Cross-sectional & $\begin{array}{l}\text { Data from the Bank of Italy } \\
\text { Household Survey of about } 8,000 \\
\text { households in Italy }\end{array}$ & 11 & $\begin{array}{l}\text { type of employment (self-employed } \\
\text { workers vs. employees) } \\
\text { public employees vs. private } \\
\text { size of the firm }(+) \\
\text { threat of unemployment }(-) \\
\text { type of contract (temporary contract vs. } \\
\text { permanent) } \\
\text { tenure (+) }\end{array}$ & \\
\hline (Somers 1995) & 1995 & $\begin{array}{l}\text { Organizational Commitment, } \\
\text { Turnover and Absenteeism: An } \\
\text { Examination of Direct and } \\
\text { Interaction Effects }\end{array}$ & Cross-sectional & $\begin{array}{l}\text { Nurses in an urban hospital in } \\
\text { the US }\end{array}$ & 233 & $\begin{array}{l}\text { affective commitment }(-) \\
\text { continuance commitment and affective } \\
\text { commitment }(-)\end{array}$ & \\
\hline
\end{tabular}


Table 1. Cont.

\begin{tabular}{|c|c|c|c|c|c|c|c|}
\hline Authors & Year & Title & Study Design & Study Population & Citations & $\begin{array}{l}\text { Determinants and Impact Direction } \\
\text { (Negative }(-) \text { or Positive }(+))\end{array}$ & Outcomes \\
\hline (Steel et al. 2007) & 2007 & $\begin{array}{l}\text { Timeframes and Absence } \\
\text { Frameworks: A Test of Steers and } \\
\text { (Rhodes' 1978) Model of } \\
\text { Attendance }\end{array}$ & Longitudinal & $\begin{array}{l}\text { Federal civil service employees in } \\
\text { the US }\end{array}$ & 9 & job satisfaction $(-)$ & \\
\hline $\begin{array}{l}\text { (Störmer and Fahr } \\
\text { 2013) }\end{array}$ & 2013 & $\begin{array}{l}\text { Individual Determinants of Work } \\
\text { Attendance: Evidence on the Role } \\
\text { of Personality }\end{array}$ & Longitudinal & $\begin{array}{l}\text { Data from the wages of } 2004 \text { to } \\
2006 \text { from the German } \\
\text { Socio-Economic Panel }\end{array}$ & 5 & $\begin{array}{l}\text { conscientiousness }(-) \\
\text { agreeableness }(-) \\
\text { neuroticism }(+)\end{array}$ & \\
\hline (Tharenou 1993) & 1993 & $\begin{array}{l}\text { A Test of Reciprocal Causality for } \\
\text { Absenteeism }\end{array}$ & Longitudinal & Electrical apprentices in Australia & 60 & $\begin{array}{l}\text { for uncertified absence: supervisory style } \\
(-)\end{array}$ & $\begin{array}{l}\text { for uncertified } \\
\text { absence: job } \\
\text { satisfaction, } \\
\text { training } \\
\text { achievement, } \\
\text { and } \\
\text { supervisor-rated } \\
\text { performance and } \\
\text { attendance (-) }\end{array}$ \\
\hline (Theorell et al. 1994) & 1994 & $\begin{array}{l}\text { 'Person Under Train' Incidents } \\
\text { from the Subway Driver's Point of } \\
\text { View-A Prospective 1-Year } \\
\text { Follow-Up Study: The Design, and } \\
\text { Medical and Psychiatric Data }\end{array}$ & Mixed method & Subway drivers in Sweden & 27 & injury (+) & \\
\hline (Torre et al. 2015) & 2015 & $\begin{array}{l}\text { Internal and External Equity in } \\
\text { Compensation Systems, } \\
\text { Organizational Absenteeism and } \\
\text { the Role of Explained Inequalities }\end{array}$ & Cross-sectional & $\begin{array}{l}\text { Data from an annual } \\
\text { labour-market survey conducted } \\
\text { by the General Confederation of } \\
\text { Italian Industry in } 2009 \text { in Italy }\end{array}$ & 4 & $\begin{array}{l}\text { internal pay equity (-) } \\
\text { external pay equity (-) (higher at } \\
\text { blue-collar workers) }\end{array}$ & \\
\hline (Vanden Heuvel 1997) & 1997 & $\begin{array}{l}\text { Absence Because Oof Family } \\
\text { Responsibilities: An Examination } \\
\text { of Explanatory Factors }\end{array}$ & Cross-sectional & $\begin{array}{l}\text { Employee data collected for the } \\
1992 \text { Australian Dependent Care } \\
\text { Study by the Australian Institute } \\
\text { of Family Studies in Australia }\end{array}$ & 18 & $\begin{array}{l}\text { job satisfaction (only for men) }(-) \\
\text { workplace flexibility (only for woman) }(-) \\
\text { child care arrangements (pre-schooler } \\
\text { parents) }(-) \\
\text { presence of dependent children }(-)\end{array}$ & \\
\hline (Vistnes 1997) & 1997 & $\begin{array}{l}\text { Gender Differences in Days Lost } \\
\text { from Work Due to Illness }\end{array}$ & Cross-sectional & $\begin{array}{l}\text { Data from the household } \\
\text { component of the } 1987 \text { National } \\
\text { Medical Expenditure Study in the } \\
\text { US }\end{array}$ & 82 & $\begin{array}{l}\text { health status (self-reported health status, } \\
\text { medical events) (both genders) (+) } \\
\text { economic variables (presence of sick leave, } \\
\text { private insurance, family income }(-) \text { for } \\
\text { woman) } \\
\text { presence of children under age six } \\
\text { (woman) }(+)\end{array}$ & \\
\hline
\end{tabular}


Table 1. Cont.

\begin{tabular}{|c|c|c|c|c|c|c|c|}
\hline Authors & Year & Title & Study Design & Study Population & Citations & $\begin{array}{l}\text { Determinants and Impact Direction } \\
\text { (Negative (-) or Positive ( }+ \text { )) }\end{array}$ & Outcomes \\
\hline (Wagar 2001) & 2001 & $\begin{array}{l}\text { Consequences of Work Force } \\
\text { Reduction: Some Employer and } \\
\text { Union Evidence }\end{array}$ & Cross-sectional & $\begin{array}{l}\text { Employer and union respondents } \\
\text { in Canada }\end{array}$ & 12 & workforce reduction $(+)$ & \\
\hline $\begin{array}{l}\text { (Waters and Roach } \\
\text { 1979) }\end{array}$ & 1979 & $\begin{array}{l}\text { Job Satisfaction, Behavioral } \\
\text { Intention, and Absenteeism as } \\
\text { Predictors of Turnover }\end{array}$ & Longitudinal & $\begin{array}{l}\text { Female clerical employees in one } \\
\text { section of a regional office of an } \\
\text { insurance company in the US }\end{array}$ & 27 & & turnover $(+)$ \\
\hline (Wegge et al. 2007) & 2007 & $\begin{array}{l}\text { 'Taking A Sickie': Job Satisfaction } \\
\text { and Job Involvement as Interactive } \\
\text { Predictors of Absenteeism in a } \\
\text { Public Organization }\end{array}$ & Cross-sectional & $\begin{array}{l}\text { Employees in a civil service } \\
\text { organization of a federal state in } \\
\text { Germany }\end{array}$ & 67 & $\begin{array}{l}\text { job involvement and job satisfaction in } \\
\text { interactions }\end{array}$ & \\
\hline (Weiner 1980) & 1980 & $\begin{array}{l}\text { Determinants and Behavioral } \\
\text { Consequences of Pay Satisfaction: } \\
\text { A Comparison of Two Models }\end{array}$ & Cross-sectional & $\begin{array}{l}\text { Employees in a medium-sized } \\
\text { ( } 350 \text { employees) public-service } \\
\text { organization }\end{array}$ & 56 & pay satisfaction $(-)$ & \\
\hline (Winkelmann 1999) & 1999 & Wages, Firm Size and Absenteeism & Longitudinal & $\begin{array}{l}\text { Data on German workers for } \\
\text { 1985-1988 from the German } \\
\text { Socio-Economic Panel }\end{array}$ & 29 & firm size (mediated with wage) $(+)$ & \\
\hline (Yang 2010) & 2010 & $\begin{array}{l}\text { Antecedents and Consequences of } \\
\text { Job Satisfaction in the Hotel } \\
\text { Industry }\end{array}$ & Cross-sectional & $\begin{array}{l}\text { Frontline employees in } \\
\text { international tourist hotels in } \\
\text { Taiwan }\end{array}$ & 75 & $\begin{array}{l}\text { job satisfaction }(-) \\
\text { organizational commitment }(-)\end{array}$ & \\
\hline (Ybema et al. 2010) & 2010 & $\begin{array}{l}\text { Antecedents and Consequences of } \\
\text { Employee Absenteeism: A } \\
\text { Longitudinal Perspective on the } \\
\text { Role of Job Satisfaction and } \\
\text { Burnout }\end{array}$ & Longitudinal & $\begin{array}{l}\text { Employee data from a cohort } \\
\text { study (Study on Musculoskeletal } \\
\text { disorders, Absenteeism, Stress } \\
\text { and Health) in the Netherlands }\end{array}$ & 55 & $\begin{array}{l}\text { job satisfaction }(-) \\
\text { burnout }(+)\end{array}$ & $\begin{array}{l}\text { job satisfaction } \\
(+) \\
\text { future absence } \\
(+)\end{array}$ \\
\hline (Zaccaro et al. 1991) & 1991 & $\begin{array}{l}\text { Prior Absenteeism, Supervisory } \\
\text { Style, Job Satisfaction, and Personal } \\
\text { Characteristics: An Investigation of } \\
\text { Some Mediated and Moderated } \\
\text { Linkages to Work Absenteeism }\end{array}$ & Cross-sectional & $\begin{array}{l}\text { Non-managerial employees of a } \\
\text { chemical manufacturing } \\
\text { company in the US }\end{array}$ & 37 & $\begin{array}{l}\text { prior absence }(+) \\
\text { job satisfaction }(-) \\
\text { gender (woman) }(+)\end{array}$ & \\
\hline $\begin{array}{l}\text { (Zeytinoglu et al. } \\
\text { 2004) }\end{array}$ & 2004 & $\begin{array}{l}\text { Part-Time and Casual Work in } \\
\text { Retail Trade: Stress and Other } \\
\text { Factors Affecting the Workplace }\end{array}$ & Cross-sectional & $\begin{array}{l}\text { Occupational health and safety } \\
\text { representatives and workers in } \\
\text { retail trade in Canada }\end{array}$ & 34 & $\begin{array}{l}\text { part-time, casual work, stress } \\
\text { (characteristics of and working conditions) } \\
(+)\end{array}$ & \\
\hline $\begin{array}{l}\text { (Zuba and Schneider } \\
\text { 2013) }\end{array}$ & 2013 & $\begin{array}{l}\text { What Helps Working Informal } \\
\text { Caregivers? The Role of Workplace } \\
\text { Characteristics in Balancing Work } \\
\text { and Adult-Care Responsibilities }\end{array}$ & Cross-sectional & $\begin{array}{l}\text { Workplace-related variables in } \\
\text { the fourth European Working } \\
\text { Condition Survey }\end{array}$ & 11 & $\begin{array}{l}\text { working contract (flexible) }(+) \\
\text { interpersonal relations at work: having } \\
\text { good friends at work }(+) \text {; } \\
\text { feeling at home at work }(-) \\
\text { family domain stressors: having children, } \\
\text { caring for a sick or disabled adult and } \\
\text { being married }(+)\end{array}$ & \\
\hline
\end{tabular}


Among the health factors that influence an employee's absence behavior, stress seems to be the most important one (Zeytinoglu et al. 2004; Kim and Garman 2003; Iverson et al. 1998).

Research shows that there is a relationship between absenteeism and many organizational and job characteristics. When it comes to firm size, larger firms seem to have higher absence rates (Scoppa 2010). Even when mediated with wages, this difference is bigger (Winkelmann 1999). Self-employed workers are less absent than workers employed by others; public workers are more absent than private workers; workers on a temporary contract are less absent than workers who have a permanent contract (Scoppa 2010). Employees with a five-day work week have smaller absence rates than employees who work four days a week (Barmby et al. 2001). Shift-turn (mornings, afternoons, and nights), days of the week (Sunday to Saturday), and position in the shift cycle (start, middle, and end cycle) also affect absenteeism (Nicholson et al. 1978).

Absence controls can have a significant effect on absence behavior (Kopelman and Schneller 1981). Improving an absence policy by introducing a punishment and reward system in the organization will reduce casual absences but also increase Family and Medical Leave Act (FMLA) absences (Johnson et al. 2014). The FMLA covers an absence caused by the birth of a child, care for a newborn or adopted child, care for an employee's spouse, child, or parent who has a serious health condition, etc.

\subsection{Outcomes of Absenteeism}

Absenteeism lowers process quality and output (Morrow et al. 1999) as well as a firm's operational efficiency (Kopelman and Schneller 1981).

Absenteeism affects other withdrawal behaviors, such as turnover. Some articles show a strong positive relationship between absenteeism and turnover (Morrow et al. 1999; Farrell and Petersen 1984; Waters and Roach 1979), while the data from (Parasuraman 1982) indicate a lagged effect between prior absenteeism and turnover.

Besides the above, the presence of absence behavior seems to aggravate overall organizational health; employees in such organizations have lower morale, high levels of stress, poor communication, and the relationships between management and staff are poor (Mchugh 2002).

Additionally, absenteeism has a negative impact on organization productivity (Herrmann and Rockoff 2012; Jung and Takeuchi 2010). The expected loss in daily productivity from employing a temporary substitute is on par with replacing a regular worker of average productivity with one at the 10th-20th percentile of productivity (Herrmann and Rockoff 2012).

\section{Discussion}

In accordance with previous research, this literature review shows that absenteeism can be caused by many personal, demographic, attitudinal, health-related, organizational, and job determinants. When considering the time dimension as defined by (Harrison and Martocchio 1998), most of the studies are dealing with long-term and mid-term causes of absenteeism, such as gender, age, family obligations and job-related attitudes.

In relation to the research questions, this literature review shows that what stand out the most as the most repetitive absenteeism causes are job satisfaction (18 times), organizational commitment (11), age (7), pay satisfaction (5), job involvement (3), and wages (3). Out of these six most-mentioned causes of absenteeism, four of them (job satisfaction, organizational commitment, pay satisfaction, and job involvement) belong to employees' attitudes. This is not a surprise since employees' attitudes in general represent one of the most researched topics of organizational behavior in general as well. This indicates that an additional, separate literature review could be performed focusing solely (separately) on employees' attitudes as predictors of absenteeism.

This research also showed that there is an evident misbalance between empirical research dealing with absenteeism determinants and research dealing with its outcomes. In the majority of research, absenteeism outcomes have negative implications: e.g., absence behavior lowers productivity, satisfaction, organizational health, outputs, and quality, while it increases turnover and costs, 
which is in line with (Goodman and Atkin 1984) conclusions. The measurement and management of absenteeism outcomes are issues of exceptional importance for every organization, not only in regard to additional costs, incurred either for the employer or for society (systems of social/health insurance, i.e., sickness benefits), but also in regard to an organization's development and sustainability.

The distribution of the publishing times of articles selected for this research, i.e., the fact that two-thirds of the analyzed articles were published in the last 20 years, shows that interest in this topic is constantly growing. The analysis also indicates a disparity in the number of articles and the industries in which this research takes place: most research deals with absenteeism in manufacturing industries, followed by hospitals and public service organizations, and then banks and insurance companies. On the other hand, some industries are strongly under-researched (e.g., tourism or the hospitality industry). This surely opens up a potentially interesting research area where it is to be expected that, due to its high labor intensity, the connections between absenteeism behavior and its causes and consequences would be easier to detect and measure.

\section{Conclusions}

Absenteeism is a crucial issue for human resource management. The understanding of absence behavior starts with an understanding of its determinants and outcomes. This article summarizes some of the possible causes and consequences of absenteeism as found in the articles of the Scopus database for a 49-year period by using the methodology of a systematic literature review. This kind of approach to the literature review has enabled the creation of an accessible pool of knowledge about the determinants and outcomes of absence behavior. It is important to emphasize that this research can be easily replicated because it followed the principles of transparency, inclusivity, explanation, and heurism.

Even though this article provides several starting points for practitioners and researchers when investigating absenteeism and its determinants and outcomes, it is not exempt from limitations: it is limited to the Scopus database, empirical evidence, and the English language. A further extension, including other databases, a review of meta-analyses and/or reviews, as well as articles in other languages, would provide interesting areas for future research.

Author Contributions: V.Č. conceived the idea for systematic review, wrote the manuscript and edited the revised versions. H.M.R. contributed through overall supervision, revision and editing of the manuscript, as well as in discussion and conclusions elaboration. K.Č. facilitated by analyzing the relevant literature and through revision. All authors read and approved the final manuscript.

Funding: This paper has been financially supported by the University of Rijeka for project ZP UNIRI 3/2016.

Conflicts of Interest: The authors declare no conflict of interest.

\section{References}

Ahn, Seungjun, Sang Hyun Lee, and Robert P. Steel. 2013. Construction Workers' Perceptions and Attitudes toward Social Norms as Predictors of their Absence Behavior. Journal of Construction Engineering and Management 140: 1-8. [CrossRef]

Arai, Mahmood, and Peter Skogman Thoursie. 2005. Incentives and Selection in Cyclical Absenteeism. Labour Economics 12: 269-80. [CrossRef]

Austrom, Douglas R., Timothy T. Baldwin, and Granger J. Macy. 1988. The Single Worker: An Empirical Exploration of Attitudes, Behavior, and Well-Being. Canadian Journal of Administrative Sciences/Revue Canadienne des Sciences de l'Administration 5: 22-29. [CrossRef]

Avery, Derek R., Sabrina D. Volpone, Patrick F. McKay, Eden B. King, and David C. Wilson. 2012. Is Relational Demography Relative? How Employment Status Influences Effects of Supervisor-subordinate Demographic similarity. Journal of Business and Psychology 27: 83-98. [CrossRef]

Bamberger, Peter, and Michal Biron. 2007. Group Norms and Excessive Absenteeism: The Role of Peer Referent Others. Organizational Behavior and Human Decision Processes 103: 179-96. [CrossRef] 
Barmby, Tim, Michael Nolan, and Rainer Winkelmann. 2001. Contracted Workdays and Absence. The Manchester School 69: 269-75. [CrossRef]

Bentley, Tim A., Bevan Catley, Helena Cooper-Thomas, Dianne Gardner, Michael P. O'Driscoll, Alison Dale, and Linda Trenberth. 2012. Perceptions of Workplace Bullying in the New Zealand Travel Industry: Prevalence and Management Strategies. Tourism Management 33: 351-60. [CrossRef]

Bitner, Mary Jo, Bernard H. Booms, and Mary Stanfield Tetreault. 1990. The Service Encounter: Diagnosing Favorable and Unfavorable Incidents. The Journal of Marketing 54: 71-84. [CrossRef]

Blau, Gary J. 1985. Relationship of Extrinsic, Intrinsic, and Demographic Predictors to Various Types of Withdrawal Behaviors. Journal of Applied Psychology 70: 442-50. [CrossRef]

Blau, Gary J. 1986. Job Involvement and Organizational Commitment as Interactive Predictors of Tardiness and Absenteeism. Journal of Management 12: 577-84. [CrossRef]

Bolin, Aaron, and Linette Heatherly. 2001. Predictors of Employee Deviance: The Relationship between Bad Attitudes and Bad Behavior. Journal of Business and Psychology 15: 405-18. [CrossRef]

Boon, Corine, Frank D. Belschak, Deanne N. Den Hartog, and Mark Pijnenburg. 2014. Perceived Human Resource Management Practices. Journal of Personnel Psychology 13: 21-33. [CrossRef]

Brooke, Paul P., and James L. Price. 1989. The Determinants of Employee Absenteeism: An Empirical Test of a Causal Model. Journal of Occupational and Organizational Psychology 62: 1-19. [CrossRef]

Brown, Sarah. 1999. Worker Absenteeism and Overtime Bans. Applied Economics 31: 165-74. [CrossRef]

Butler, Richard J., B. Delworth Gardner, and Harold H. Gardner. 1998. More than Cost Shifting: Moral Hazard Lowers Productivity. Journal of Risk and Insurance 65: 671-88. [CrossRef]

Byron, Kristin, and Suzanne Peterson. 2002. The Impact of a Large-Scale Traumatic Event on Individual and Organizational Outcomes: Exploring Employee and Company Reactions to September 11, 2001. Journal of Organizational Behavior 23: 895-910. [CrossRef]

Carmeli, Abraham, Revital Shalom, and Jacob Weisberg. 2007. Considerations in Organizational Career Advancement: What Really Matters. Personnel Review 36: 190-205. [CrossRef]

Chadwick-Jones, John K., Colin A. Brown, Nigel Nicholson, and C. Sheppard. 1971. Absence Measures: Their Reliability and Stability in an Industrial Setting. Personnel Psychology 24: 463-70. [CrossRef]

Cheloha, Randall S., and James L. Farr. 1980. Absenteeism, Job Involvement, and Job Satisfaction in an Organizational Setting. Journal of Applied Psychology 65: 467-73. [CrossRef] [PubMed]

Chullen, C. Logan, Benjamin B. Dunford, Ingo Angermeier, R. Wayne Boss, and Alan D. Boss. 2010. Minimizing Deviant Behavior in Healthcare Organizations: The Effects of Supportive Leadership and Job Design. Journal of Healthcare Management 55: 381-97. [CrossRef] [PubMed]

Chung, Beth G., and Benjamin Schneider. 2002. Serving Multiple Masters: Role Conflict Experienced by Service Employees. Journal of Services Marketing 16: 70-87. [CrossRef]

Cohen, Aaron. 1998. An Examination of the Relationship between Work Commitment and Work Outcomes among Hospital Nurses. Scandinavian Journal of Management 14: 1-17. [CrossRef]

Cohen, Aaron, and Ronit Golan. 2007. Predicting Absenteeism and Turnover Intentions by Past Absenteeism and Work Attitudes: An Empirical Examination of Female Employees in Long Term Nursing Care Facilities. Career Development International 12: 416-32. [CrossRef]

Colquitt, Jason A., Raymond A. Noe, and Christine L. Jackson. 2002. Justice in Teams: Antecedents and Consequences of Procedural Justice Climate. Personnel Psychology 55: 83-109. [CrossRef]

Cornelissen, Thomas, Oliver Himmler, and Tobias Koenig. 2013. Fairness Spillovers-The Case of Taxation. Journal of Economic Behavior E Organization 90: 164-80. [CrossRef]

Cucchiella, Federica, Massimo Gastaldi, and Luigi Ranieri. 2014. Managing Absenteeism in the Workplace: The Case of an Italian Multiutility Company. Procedia-Social and Behavioral Sciences 150: 1157-66. [CrossRef]

Daouk-Öyry, Lina, Abdel-Latef Anouze, Farah Otaki, Nuhad Yazbik Dumit, and Ibrahim Osman. 2014. The JOINT Model of Nurse Absenteeism and Turnover: A Systematic Review. International Journal of Nursing Studies 51: 93-110. [CrossRef] [PubMed]

Dasgupta, Shilpee A., Damodar Suar, and Seema Singh. 2012. Impact of Managerial Communication Styles on Employees' Attitudes and Behaviours. Employee Relations 35: 173-99. [CrossRef]

Davey, Mandy M., Greta Cummings, Christine V. Newburn-Cook, and Eliza A. Lo. 2009. Predictors of Nurse Absenteeism in Hospitals: A Systematic Review. Journal of Nursing Management 17: 312-30. [CrossRef] [PubMed] 
De Boer, Elpine M., Arnold B. Bakker, Jef E. Syroit, and Wilmar B. Schaufeli. 2002. Unfairness at Work as a Predictor of Absenteeism. Journal of Organizational Behavior 23: 181-97. [CrossRef]

Deery, Stephen J., and Roderick D. Iverson. 2005. Labor-Management Cooperation: Antecedents and Impact on Organizational Performance. ILR Review 58: 588-609. [CrossRef]

Deery, Stephen J., Peter J. Erwin, Roderick D. Iverson, and Margaret L. Ambrose. 1995. The Determinants of Absenteeism: Evidence from Australian Blue-Collar Employees. International Journal of Human Resource Management 6: 825-48. [CrossRef]

Deery, Stephen J., Roderick D. Iverson, Donna M. Buttigieg, and Christopher D. Zatzick. 2014. Can Union Voice Make a Difference? The Effect of Union Citizenship Behavior on Employee Absence. Human Resource Management 53: 211-28. [CrossRef]

Dehue, Francine, Catherine Bolman, Trijntje Völlink, and Mieneke Pouwelse. 2012. Coping with Bullying at Work and Health Related Problems. International Journal of Stress Management 19: 175-97. [CrossRef]

Denyer, David, and David Tranfield. 2009. Producing a Systematic Review. In The SAGE Handbook of Organizational Research Methods. Edited by David Buchanan and Alan Bryman. London: SAGE Publications Ltd., pp. 671-89.

Diestel, Stefan, and Klaus-Helmut Schmidt. 2012. Lagged Mediator Effects of Self-Control Demands on Psychological Strain and Absenteeism. Journal of Occupational and Organizational Psychology 85: 556-78. [CrossRef]

Dionne, Georges, and Benoit Dostie. 2007. New Evidence on the Determinants of Absenteeism Using Linked Employer-Employee Data. ILR Review 61: 108-20. [CrossRef]

Drakopoulos, Stavros A., and Katerina Grimani. 2013. Injury-Related Absenteeism and Job Satisfaction: Insights from Greek and UK Data. The International Journal of Human Resource Management 24: 3496-511. [CrossRef]

Duff, Angus J., Mark Podolsky, Michal Biron, and Christopher C. A. Chan. 2015. The Interactive Effect of Team and Manager Absence on Employee Absence: A Multilevel Field Study. Journal of Occupational and Organizational Psychology 88: 61-79. [CrossRef]

Durand, V. Mark. 1985. Employee Absenteeism: A Selective Review of Antecedents and Consequences. Journal of Organizational Behavior Management 7: 135-68. [CrossRef]

Farrell, Dan, and James C. Petersen. 1984. Commitment, Absenteeism, and Turnover of New Employees: A Longitudinal Study. Human Relations 37: 681-92. [CrossRef]

Festing, Marion, Yvonne Groening, Rudiger Kabst, and Wolfgang Weber. 1999. Financial Participation in Europe-Determinants and Outcomes. Economic and Industrial Democracy 20: 295-329. [CrossRef]

Frick, Bernd, and Miguel Á. Malo. 2008. Labor Market Institutions and Individual Absenteeism in the European Union: The Relative Importance of Sickness Benefit Systems and Employment Protection Legislation. Industrial Relations: A Journal of Economy and Society 47: 505-29. [CrossRef]

Frooman, Jeff, Morris B. Mendelson, and J. Kevin Murphy. 2012. Transformational and Passive Avoidant Leadership as Determinants of Absenteeism. Leadership E Organization Development Journal 33: 447-63. [CrossRef]

Fugate, Mel, Gregory E. Prussia, and Angelo J. Kinicki. 2012. Managing Employee Withdrawal during Organizational Change: The Role of Threat Appraisal. Journal of Management 38: 890-914. [CrossRef]

Garcia, Richard L. 1987. Sick-Time Usage by Management and Professional Employees in the Public Sector. Review of Public Personnel Administration 7: 45-59. [CrossRef]

Garrison, Kathleen R., and Paul M. Muchinsky. 1977. Attitudinal and Biographical Predictors of Incidental Absenteeism. Journal of Vocational Behavior 10: 221-30. [CrossRef]

Gellatly, Ian R. 1995. Individual and Group Determinants of Employee Absenteeism: Test of a Causal Model. Journal of Organizational Behavior 16: 469-85. [CrossRef]

Gellatly, Ian R., and Andrew A. Luchak. 1998. Personal and Organizational Determinants of Perceived Absence Norms. Human Relations 51: 1085-102. [CrossRef]

Gerstenfeld, Arthur. 1969. Employee Absenteeism: New Insights: Data Reveal External Factors. Business Horizons 12: 51-57. [CrossRef]

Gibson, R. Oliver. 1966. Toward a Conceptualization of Absence Behavior of Personnel in Organization. Administrative Science Quarterly 11: 107-33. [CrossRef]

Goldberg, Caren B., and David A. Waldman. 2000. Modeling Employee Absenteeism: Testing Alternative Measures and Mediated Effects Based on Job Satisfaction. Journal of Organizational Behavior 21: 665-76. [CrossRef] 
Goodman, Paul S., and Robert S. Atkin. 1984. Effects of Absenteeism on Individuals and Organizations. Tepper School of Business. Paper 848. Available online: http:/ / repository.cmu.edu/tepper/848 (accessed on 5 July 2018).

Harrison, David A., and Joseph J. Martocchio. 1998. Time for Absenteeism: A 20-Year Review of Origins, Offshoots, and Outcomes. Journal of Management 24: 305-50. [CrossRef]

Hassan, Shahidul, Bradley E. Wright, and Gary Yukl. 2014. Does Ethical Leadership Matter in Government? Effects on Organizational Commitment, Absenteeism, and Willingness to Report Ethical Problems. Public Administration Review 74: 333-43. [CrossRef]

Hattrup, Keith, Matthew S. O'Connell, and Peter H. Wingate. 1998. Prediction of Mulitdimensional Criteria: Distinguishing Task and Contextual Performance. Human Performance 11: 305-19. [CrossRef]

Hausknecht, John P., Nathan J. Hiller, and Robert J. Vance. 2008. Work-Unit Absenteeism: Effects of Satisfaction, Commitment, Labor Market Conditions, and Time. Academy of Management Journal 51: 1223-45. [CrossRef]

Hemingway, Monica A., and Carlla S. Smith. 1999. Organizational Climate and Occupational Stressors as Predictors of Withdrawal Behaviours and Injuries in Nurses. Journal of Occupational and Organizational Psychology 72: 285-99. [CrossRef]

Herrmann, Mariesa A., and Jonah E. Rockoff. 2012. Worker Absence and Productivity: Evidence from Teaching. Journal of Labor Economics 30: 749-82. [CrossRef]

Ichino, Andrea, and Regina T. Riphahn. 2005. The Effect of Employment Protection on Worker Effort: Absenteeism During and After Probation. Journal of the European Economic Association 3: 120-43. [CrossRef]

Ivancevich, John M. 1986. Life Events and Hassles as Predictors of Health Symptoms, Job Performance, and Absenteeism. Journal of Organizational Behavior 7: 39-51. [CrossRef]

Iverson, Roderick D., and Donna M. Buttigieg. 1999. Affective, Normative and Continuance Commitment: Can the 'Right Kind' of Commitment Be Managed? Journal of Management Studies 36: 307-33. [CrossRef]

Iverson, Roderick D., Mara Olekalns, and Peter J. Erwin. 1998. Affectivity, Organizational Stressors, and Absenteeism: A Causal Model of Burnout and Its Consequences. Journal of Vocational Behavior 52: 1-23. [CrossRef]

Johns, Gary. 1978. Attitudinal and Nonattitudinal Predictors of Two Forms of Absence from Work. Organizational Behavior and Human Performance 22: 431-44. [CrossRef]

Johnson, Jonathan L., and Anne M. O'Leary-Kelly. 2003. The Effects of Psychological Contract Breach and Organizational Cynicism: Not All Social Exchange Violations are Created Equal. Journal of Organizational Behavior 24: 627-47. [CrossRef]

Johnson, Michael D., Erica C. Holley, Frederick P. Morgeson, Deborah Labonar, and Adam Stetzer. 2014. Outcomes of Absence Control Initiatives: A Quasi-Experimental Investigation into the Effects of Policy and Perceptions. Journal of Management 40: 1075-97. [CrossRef]

Jones, James R., Jinlan Ni, and David C. Wilson. 2009. Comparative Effects of Race/Ethnicity and Employee Engagement on Withdrawal Behavior. Journal of Managerial Issues 21: 195-215.

Judge, Timothy A., and Joseph J. Martocchio. 1996. Dispositional Influences on Attributions Concerning Absenteeism. Journal of Management 22: 837-61. [CrossRef]

Jung, Yuhee, and Norihiko Takeuchi. 2010. Performance Implications for the Relationships among Top Management Leadership, Organizational Culture, and Appraisal Practice: Testing Two Theory-Based Models of Organizational Learning Theory in Japan. The International Journal of Human Resource Management 21: 1931-50. [CrossRef]

Kim, Jinhee, and E. Thomas Garman. 2003. Financial Stress and Absenteeism: An Empirically Derived Model. Journal of Financial Counseling and Planning 14: 31-42.

Kolz, Arno R. 1999. Personality Predictors of Retail Employee Theft and Counterproductive Behavior. Journal of Professional Services Marketing 19: 107-14. [CrossRef]

Kopelman, Richard E., and George O. Schneller IV. 1981. A Mixed-Consequence System for Reducing Overtime and Unscheduled Absences. Journal of Organizational Behavior Management 3: 17-28. [CrossRef]

Krausz, Moshe, Meni Koslowsky, and Asher Eiser. 1998. Distal and Proximal Influences on Turnover Intentions and Satisfaction: Support for a Withdrawal Progression Theory. Journal of Vocational Behavior 52: 59-71. [CrossRef]

Kristensen, Kai, Hans Jørn Juhl, Jacob Eskildsen, Jesper Nielsen, Niels Frederiksen, and Carsten Bisgaard. 2006. Determinants of Absenteeism in a Large Danish Bank. The International Journal of Human Resource Management 17: 1645-58. [CrossRef] 
Landeweerd, Jan A., and Nicolle P. G. Boumans. 1994. The Effect of Work Dimensions and Need for Autonomy on Nurses' Work Satisfaction and Health. Journal of Occupational and Organizational Psychology 67: 207-17. [CrossRef]

Leśniowska, Joanna, Agata Schubert, Michał Wojna, Iwona Skrzekowska-Baran, and Marta Fedyna. 2014. Costs of Diabetes and Its Complications in Poland. The European Journal of Health Economics 15: 653-60. [CrossRef] [PubMed]

Løkke, Ann-Kristina, Jacob K. Eskildsen, and Troels Wendelboe Jensen. 2006. Absenteeism in the Nordic Countries. Employee Relations 29: 16-29. [CrossRef]

Løkke Nielsen, Ann-Kristina. 2008. Determinants of Absenteeism in Public Organizations: A Unit-Level Analysis of Work Absence in a Large Danish Municipality. The International Journal of Human Resource Management 19: 1330-48. [CrossRef]

March, James. G., and Herbert Alexander Simon. 1958. Organizations, 2nd ed. New York: Wiley.

Mason, Claire M., and Mark A. Griffin. 2003. Group Absenteeism and Positive Affective Tone: A Longitudinal Study. Journal of Organizational Behavior 24: 667-87. [CrossRef]

Mathis, Robert L., and John H. Jackson. 2004. Human Resource Management, 12th ed. International Student Edition. Mason: Thomson South-Western.

Mchugh, Marie. 2002. The Absence Bug: A Treatable Viral Infection? Journal of Managerial Psychology 17: 722-38. [CrossRef]

Morrow, Paula C., James C. Mcelroy, Kathleen S. Laczniak, and James B. Fenton. 1999. Using Absenteeism and Performance to Predict Employee Turnover: Early Detection through Company Records. Journal of Vocational Behavior 55: 358-74. [CrossRef]

Moscarola, Flavia Coda, Elsa Fornero, and Steinar Strøm. 2016. Absenteeism, Childcare and the Effectiveness of Pension Reforms. IZA Journal of European Labor Studies 5: 1-18. [CrossRef]

Muchinsky, Paul M. 1977. Employee Absenteeism: A Review of the Literature. Journal of Vocational Behavior 10: 316-40. [CrossRef]

Mukhopadhyay, Tridas, Surendra Rajiv, and Kannan Srinivasan. 1997. Information Technology Impact on Process Output and Quality. Management Science 43: 1645-59. [CrossRef]

Nguyen, Helena, Markus Groth, and Anya Johnson. 2016. When the Going Gets Tough, the Tough Keep Working: Impact of Emotional Labor on Absenteeism. Journal of Management 42: 615-43. [CrossRef]

Nicholson, Nigel, Paul Jackson, and Gillian Howes. 1978. Shiftwork and Absence: An Analysis of Temporal Trends. Journal of Occupational and Organizational Psychology 51: 127-37. [CrossRef]

Nickson, Dennis, Tom Baum, Erwin Losekoot, and Alison Morrison. 2002. Skills, Organisational Performance and Economic Activity in the Hospitality Industry: A Literature Review. Oxford: University of Oxford and Warwick, Economic and Social Research Council Centre for Skills, Knowledge, and Organizational Performance (SKOPE).

Orpen, Christopher. 1979. The Effects of Job Enrichment on Employee Satisfaction, Motivation, Involvement, and Performance: A Field Experiment. Human Relations 32: 189-217. [CrossRef]

Parasuraman, Saroj. 1982. Predicting Turnover Intentions and Turnover Behavior: A Multivariate Analysis. Journal of Vocational Behavior 21: 111-21. [CrossRef]

Pizam, Abraham, and Steven W. Thornburg. 2000. Absenteeism and Voluntary Turnover in Central Florida Hotels: A Pilot Study. International Journal of Hospitality Management 19: 211-17. [CrossRef]

Price, James L. 1998. Estimation of Causal Model of Absenteeism. Indian Journal of Labour Economics 41: 227-46.

Punnett, Betty Jane, Dion Greenidge, and Jase Ramsey. 2007. Job Attitudes and Absenteeism: A Study in the English Speaking Caribbean. Journal of World Business 42: 214-27. [CrossRef]

Qin, Xin, and Yuexin Jiang. 2011. The Impact of Natural Disaster on Absenteeism, Job Satisfaction, and Job Performance of Survival Employees: An Empirical Study of the Survivors in Wenchuan Earthquake. Frontiers of Business Research in China 5: 219-42. [CrossRef]

Redman, Tom, Peter Hamilton, Hedley Malloch, and Birgit Kleymann. 2011. Working Here Makes Me Sick! The Consequences of Sick Building Syndrome. Human Resource Management Journal 21: 14-27. [CrossRef]

Rentsch, Joan R., and Robert P. Steel. 1998. Testing the Durability of Job Characteristics as Predictors of Absenteeism over a Six-Year Period. Personnel Psychology 51: 165-90. [CrossRef]

Rhodes, Susan, and Richard Steers. 1981. A Systematic Approach to Diagnosing Employee Absenteeism. Employee Relations 3: 17-22. [CrossRef] 
Røed, Knut, and Elisabeth Fevang. 2007. Organizational Change, Absenteeism, and Welfare Dependency. Journal of Human Resources 42: 156-93. [CrossRef]

Rosse, Joseph G., and Charles L. Hulin. 1985. Adaptation to Work: An Analysis of Employee Health, Withdrawal, and Change. Organizational Behavior and Human Decision Processes 36: 324-47. [CrossRef]

Saha, Somnath, Sanjay Saint, and Dimitri A. Christakis. 2003. Impact Factor: A Valid Measure of Journal Quality? Journal of the Medical Library Association 91: 42-46. [PubMed]

Saxton, Mary Jane, James S. Phillips, and Roger N. Blakeney. 1991. Antecedents and Consequences of Emotional Exhaustion in the Airline Reservations Service Sector. Human Relations 44: 583-95. [CrossRef]

Schneider, Benjamin, Ellen G. Godfrey, Seth C. Hayes, Mina Huang, Beng-Chong Lim, Lisa Hisae Nishii, Jana L. Raver, and Jonathan C. Ziegert. 2003. The Human Side of Strategy: Employee Experiences of Strategic Alignment in a Service Organization. Organizational Dynamics 32: 122-41. [CrossRef]

Scoppa, Vincenzo. 2010. Worker Absenteeism and Incentives: Evidence from Italy. Managerial and Decision Economics 31: 503-15. [CrossRef]

Somers, Mark John. 1995. Organizational Commitment, Turnover and Absenteeism: An Examination of Direct and Interaction Effects. Journal of Organizational Behavior 16: 49-58. [CrossRef]

Steel, Robert P. 2003. Methodological and Operational Issues in the Construction of Absence Variables. Human Resource Management Review 13: 243-51. [CrossRef]

Steel, Robert P., Joan R. Rentsch, and James R. Van Scotter. 2007. Timeframes and Absence Frameworks: A Test of Steers and Rhodes' (1978) Model of Attendance. Journal of Management 33: 180-95. [CrossRef]

Störmer, Susi, and René Fahr. 2013. Individual Determinants of Work Attendance: Evidence on the Role of Personality. Applied Economics 45: 2863-75. [CrossRef]

Tharenou, Phyllis. 1993. A Test of Reciprocal Causality for Absenteeism. Journal of Organizational Behavior 14: 269-87. [CrossRef]

Theorell, Tores, Heinz Leymann, Margareta Jodko, Kristoffer Konarski, and Hans Erik Norbeck. 1994. ‘Person Under Train' Incidents from the Subway Driver's Point of View-A Prospective 1-Year Follow-Up Study: The Design, and Medical and Psychiatric Data. Social Science \& Medicine 38: 471-75. [CrossRef]

Torre, Edoardo Della, Matteo Pelagatti, and Luca Solari. 2015. Internal and External Equity in Compensation Systems, Organizational Absenteeism and the Role of Explained Inequalities. Human Relations 68: 409-40. [CrossRef]

Tranfield, David, David Denyer, and Palminder Smart. 2003. Towards a Methodology for Developing Evidence-Informed Management Knowledge by Means of Systematic Review. British Journal of Management 14: 207-22. [CrossRef]

Vanden Heuvel, Audrey. 1997. Absence Because of Family Responsibilities: An Examination of Explanatory Factors. Journal of Family and Economic Issues 18: 273-97. [CrossRef]

Vistnes, Jessica Primoff. 1997. Gender Differences in Days Lost from Work Due to Illness. ILR Review 50: $304-23$. [CrossRef]

Wagar, Terry H. 2001. Consequences of Work Force Reduction: Some Employer and Union Evidence. Journal of Labor Research 22: 851-62. [CrossRef]

Waters, L. K., and Darrell Roach. 1979. Job Satisfaction, Behavioral Intention, and Absenteeism as Predictors of Turnover. Personnel Psychology 32: 393-97. [CrossRef]

Wegge, Jürgen, Klaus-Helmut Schmidt, Carole Parkes, and Rolf Dick. 2007. Taking a Sickie: Job Satisfaction and Job Involvement as Interactive Predictors of Absenteeism in a Public Organization. Journal of Occupational and Organizational Psychology 80: 77-89. [CrossRef]

Weiner, Nan. 1980. Determinants and Behavioral Consequences of Pay Satisfaction: A Comparison of Two Models. Personnel Psychology 33: 741-57. [CrossRef]

Winkelmann, Rainer. 1999. Wages, Firm Size and Absenteeism. Applied Economics Letters 6: 337-41. [CrossRef]

Yang, Jen-Te. 2010. Antecedents and Consequences of Job Satisfaction in the Hotel Industry. International Journal of Hospitality Management 29: 609-19. [CrossRef]

Ybema, Jan F., Peter GW Smulders, and Paulien M. Bongers. 2010. Antecedents and Consequences of Employee Absenteeism: A Longitudinal Perspective on the Role of Job Satisfaction and Burnout. European Journal of Work and Organizational Psychology 19: 102-24. [CrossRef] 
Zaccaro, Stephen J., Barbara Craig, and Jeffrey Quinn. 1991. Prior Absenteeism, Supervisory Style, Job Satisfaction, and Personal Characteristics: An Investigation of Some Mediated and Moderated Linkages to Work Absenteeism. Organizational Behavior and Human Decision Processes 50: 24-44. [CrossRef]

Zeytinoglu, Isik, Waheeda Lillevik, Bianca Seaton, and Josefina Moruz. 2004. Part-Time and Casual Work in Retail Trade: Stress and Other Factors Affecting the Workplace. Relations Industrielles/Industrial Relations 59: 516-44. [CrossRef]

Zuba, Martin, and Ulrike Schneider. 2013. What Helps Working Informal Caregivers? The Role of Workplace Characteristics in Balancing Work and Adult-Care Responsibilities. Journal of Family and Economic Issues 34: 460-69. [CrossRef]

(C) 2018 by the authors. Licensee MDPI, Basel, Switzerland. This article is an open access article distributed under the terms and conditions of the Creative Commons Attribution (CC BY) license (http:/ / creativecommons.org/licenses/by/4.0/). 